\title{
Motor Neuron Cell Death in Wobbler Mutant Mice Follows Overexpression of the G-protein-coupled, Protease-activated Receptor for Thrombin
}

\author{
Barry W. Festoff ${ }^{1,2}$, Michael R. D'Andrea3 ${ }^{3}$ Bruce A. Citron $^{1,2}$, \\ Raymundo M. Salcedo', Irina V. Smirnova', and Patricia Andrade-Gordon ${ }^{3}$ \\ ${ }^{1}$ Neurobiology Research Laboratory, Department of Veterans Affairs Medical Center, \\ Kansas City, Missouri, U.S.A. \\ ${ }^{2}$ Departments of Neurology, Pharmacology, Toxicology and Therapeutics, University \\ of Kansas Medical Center, Kansas City, Kansas, U.S.A. \\ ${ }^{3}$ Drug Discovery, The R. W. Johnson Pharmaceutical Research Institute, Spring \\ House, Pennsylvania, U.S.A.
}

Accepted February 7, 2000.

\begin{abstract}
Background: Mechanisms underlying neurodegeneration are actively sought for new therapeutic strategies. Transgenic, knockout and genetic mouse models greatly aid our understanding of the mechanisms for neuronal cell death. A naturally occurring, autosomal recessive mutant, known as wobbler, and mice transgenic for familial amyotrophic lateral sclerosis $\left(\right.$ FALS $^{1}$ ) superoxide dismutase (SOD) 1 mutations are available, but the molecular mechanisms remain equally unknown. Both phenotypes are detectable after birth. Wobbler is detectable in the third week of life, when homozygotes (wr/wr) exhibit prominent gliosis and significant motor neuron loss in the cervical, but not in lumbar, spinal cord segments. To address molecular mechanisms, we evaluated "death signals" associated with the multifunctional serine protease, thrombin, which leads to apoptotic motor neuronal cell death in culture by cleavage of a G-protein coupled, protease-activated receptor 1 (PAR-1).

Materials and Methods: Thrombin activities were determined with chromogenic substrate assays, Western immunoblots and immunohistochemistry were performed with anti-PAR-1 to observe localizations of the receptor and anti-GFAP staining was used to monitor astrocytosis. PAR-1 mRNA levels and locations were determined by reverse transcription polymerase chain reaction (qRT-PCR) and in
\end{abstract}

situ hybridizations. Cell death was monitored with in situ DNA fragmentation assays.

Results: In preliminary studies we found a 5-fold increase in PAR-1 mRNA in cervical spinal cords from $w r / w r$, compared with wild-type (wt) littermates. Our current studies suggested that reactive astrocytosis and motor neuron cell death were causally linked with alterations in thrombin signaling. PAR-1 protein expression was increased, as demonstrated by immunocytochemistry and confirmed with in situ hybridization, in phenotypic $w r / w r$ motor neurons, compared with $w t$, but not in astrocytes. This increase was much greater in cervical, compared with lumbar, segments, paralleling motor neuron degeneration. We also found, using reverse transcription polymerase chain reaction (qRT-PCR) with RNA from genotyped embryos, that PAR-1 was already increased in $w r / w r$ cords at E12, the earliest time examined.

Conclusions: Thus, motor neuron degeneration and death follows PAR-1 expression both temporally and topographically in wobbler mice. Since our culture studies show that thrombin mobilized $\left[\mathrm{Ca}^{2+}\right]_{i}$ by activating PAR-1, eventually leading to motor neuron apoptosis, up-regulation of PAR-1 during development may contribute both to "appropri-

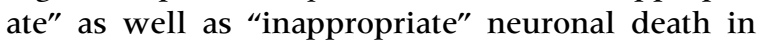
wobbler.

\section{Introduction}

In addition to "appropriate" apoptosis in the developing nervous system, evidence for "in- appropriate" apoptosis is well-documented for a number of neurodegenerative diseases $(1,2)$. In both animal and human motor neuron dis- 
orders, motor neuron death is a prominent feature, but the precise percentage of apoptosis is still uncertain. Motor neurons appear to be particularly sensitive to cell death, but over the last few years, mechanisms accounting for the selective motor neuron vulnerability and their progressive death have been difficult to define. Some information comes from studies of mutations in $\mathrm{Cu} / \mathrm{Zn}$-superoxide dismutase (SOD) (EC 1.15.1.1; SOD1), an example of apoptotic motor neuron loss. SODl mutations account for $20 \%$ of familial amyotrophic lateral sclerosis (FALS), which comprises $5-10 \%$ of all ALS (3-6). SODl transgenic mice develop amyotrophic lateral sclerosis (ALS)-like symptoms (7) through a proapoptotic "toxic gain-offunction" mechanism (8-10). This implicates oxygen-free radical (OFR) sensitivity and greatly aids the understanding of OFR-induced damage to motor neurons $(11,12)$.

The spontaneous autosomal recessive wobbler mutation, has been in active study as a model for motor neuron degeneration for more than 40 years (13). Homozygotic wobbler mice undergo prominent, progressive motor neuron degeneration in spinal cord and brainstem (14). This suggests their use as a model for ALS and spinal muscular atrophy (SMA), particularly infantile Werdnig-Hoffman disease (12). Subsequently bred on many strain backgrounds, the wobbler ( $w r$ ) gene was localized to proximal mouse chromosome 11 (15), where it was tightly linked to the intronless glutamine synthase pseudogene 1 (Glns-ps1) and Rabl $(16,17)$, a GTP binding protein of the ras oncogene family. The polymorphic microsatellite marker, Glns-ps1, was previously exploited (18) by crossing $+/ w r$ with New Zealand Black (NZB) mice, thereby allowing preclinical detection of the $w r / w r$ genotype (19-21). Preclinical detection would facilitate studies to establish precise onset of motor neuron cell death and elucidation of the responsible mechanisms.

Active expression of the wobbler phenotype was reported previously to not be detected until 3-6 weeks after birth (22), with early vacuolar motor neuronal degeneration and sub-

Address correspondence and reprint requests to: Barry W. Festoff, M.D., Neurobiology Research Laboratory (151), Department of Veterans Affairs Medical Center, University of Kansas Medical Center, 4801 Linwood Blvd., Kansas City, Missouri 64128, U.S.A. Phone: 816-861-4700, ext. 7079/7072; Fax: 816-922-3375; E-mail:

serpin@eagle.cc.ukans.edu sequent cell shrinkage leading to reduced numbers in cervical cord and brainstem. Other reports suggested much earlier detection of the phenotype (23). Surprisingly, using profile methods, the number of motor neurons in $w r / w r$ phrenic nerve nucleus remained relatively unchanged, compared with $w t$ littermates, up until postnatal day 21 (P21;22). Since genotyping was unavailable, preclinical motor neuron counts were not determined and other counting methods $(24,25)$ were not used. High copy number FALS transgenic mice also show early vacuolar degeneration of motor neurons and fragmentation of the Golgi apparatus $(7,26)$. Subsequent shrinkage of motor neurons and cell loss, changes most often seen in both sporadic amyotrophic lateral sclerosis (SALS) and FALS patients (27), are seen in low expression SOD 1 transgenic mice.

Although, in dividing cells, thrombin promotes proliferation as a growth factor, this multi-functional serine protease kills neurons in culture at nanomolar concentrations by activating the thrombin protease-activated receptor 1 (PAR-1;28-30). One laboratory reported "protection," primarily in astrocytes, at very low (pM) concentrations $(28,31)$. Recent studies with mouse $(32,33)$ and chick $(34)$ motor neurons, as well as rat primary hippocampal neurons (35), have shown that apoptosis is the major mode of neuronal death, signaled through PAR-1. Earlier, we observed that PAR1 mRNA was increased in $w r / w r$ spinal cords (36) using a quantitative reverse transcription polymerase chain reaction (qRT-PCR) strategy. In the present experiments, we extended those observations by finding that this overexpression is concentrated in those cells bearing the disease burden, the alpha motor neurons in the cervical region. Remarkably, this up-regulation of PAR- 1 is already found at the earliest time studied, embryonic day 12 (E12), more than a month before classical phenotypic detection.

\section{Materials and Methods}

\section{Materials}

Wobbler breeding pairs $(N F R / N-w r /+)$ were obtained from Drs. Carl Hanson and James Crowell (Genetic Resource Section, National Center for Research Resources, National Institutes of Health, Bethesda, MD) to establish a colony at the Kansas City Veterans Administration Medical Center's Animal Research Facility (KCVAARF), according to established 
protocols. We obtained breeding pairs of NZB mice from Dr. Sarah Walker (VA Medical Center, Columbia, MO). All protocols were approved by the Kansas City VA Medical Center (KCVAMC) animal care and use committee and met NIH guidelines.

Polyclonal immunoglobulin G (IgG) isotype antibodies included rabbit anti-rat PAR-1 from the Robert Woods Johnson Pharmaceutical Research Institute (Spring House, PA), used at $2 \mu \mathrm{g} / \mathrm{ml}$; rabbit anti-human glial fibrillary acidic protein (GFAP) from Chemicon (Temecula, CA), used at a 1:2000 dilution; and rabbit anti-bovine neuron-specific enolase (NSE) from DAKO (Carpenteria, CA), used at a 1:4000 dilution. Commercial antibodies (other than those listed above), the immunohistochemistry detection system, and 3,3'-diaminobenzidine were purchased either from Biomeda (Foster City, CA) or DAKO. An avidin-biotin blocking system, biotinylated secondary antibodies, goat anti-rabbit (polyclonal antibodies), horse anti-mouse (monoclonal antibodies), and avidin-biotin-horse radish peroxidase (HRP) complex reagent, were all purchased from Vector Labs (Burlingame, CA). Antibody diluent was from Zymed Laboratories, Inc. (San Francisco, CA) and Target reagent was from DAKO. Pre-cast sodium dodecylsulfate-polyacrylamide gels (SDS-PAGE) were purchased from Novex (San Diego, CA). Nonfat dried milk and nitrocellulose membranes were obtained from Biorad (Hercules, CA) and polyvinylidene difluoride (PVDF) membranes were purchased from Millipore (Bedford, MA). The enhanced chemiluminescence (ECL) kit was purchased from Amersham (Arlington Heights, IL). PlusSuperfrost slides were from VWR (Piscataway, $\mathrm{NJ}$ ), proteinase $\mathrm{K}$ from DAKO, hybridization buffer from Biomeda and Permount was from Fisher Scientific (Pittsburgh, PA). DNTPs (dCTP, dGTP, dTTP) were from Boehringer Mannheim (Indianapolis, IN), biotin-14-dATP from Gibco-BRL (Grand Island, NY), DNA polymerase I and terminal deoxynucleotidyl transferase (TdT) were from Promega (Madison, WI).

RNase $\mathrm{H}^{-}$reverse transcriptase (Superscript II), RNase inhibitor, and T7 RNA polymerase were obtained from Bethesda Research Labs (Gaithersburg, MD). RNase-free DNase I was obtained from Sigma (St. Louis, MO). Taq polymerase, Amplitaq and PCR mix was from Perkin Elmer (Norwalk, CT), and Klenow en- zyme was from Boehringer Mannheim, $\mathrm{GmbH}$ (Mannheim, Germany). Guanidine thiocyanate/phenol reagent, Tri Reagent, was from Molecular Research Center (Cincinnati, $\mathrm{OH}$ ), and other organic reagents were from J. T. Baker (Phillipsburg, NJ). The $\Delta$ Genozyme Cycle Sequencing Kit and Genomyx LR DNA gel apparatus were from Genomyx (Foster City, CA). Agarose was purchased from FMC (Rockland, ME). The in situ hybridization probes were made at Research Genetics (Huntsville, AL) and were 3'-biotinylated with Brigati Tails (six biotins in a row connected to the $3^{\prime}$ end of the probe). The PAR-1 probe sequence was TTC ATT TTT CTC CTC CTC CTC CTC ATC.

\section{Astrocyte Culture}

Astrocytes were cultured from 28-day-old $w r / w r$ and $w t$ littermate whole spinal cords as described previously (37). To obtain conditioned medium, fresh dissociated cells were plated in $80 \%$ Modified Eagle's Medium (MEM) and 20\% medium 199 (both from GIBCO, Grand Island, NY) for 8 days in vitro.

\section{PAR Antibody Production}

A rabbit was immunized with a synthetic peptide corresponding to the sequence, LLSSRVPMSQPESERC, which were identical to mouse PAR-1 residues 19-33. The peptide was coupled to keyhole limpet hemocyanin (KLH) through the C-terminal Cys and used to generate a rabbit polyclonal antibody (PAR-1C). This PAR-1C antibody was characterized previously $(38,39)$ and shown not to label proteins in mice lacking PAR-1 (40).

\section{Preparation of Tissue for Morphologic Studies}

Mice were deeply anesthetized with an intraperitoneal injection of $40 \mu \mathrm{l} / \mathrm{g}$ of a rodent cocktail [ketamine $5 \mathrm{mg} / \mathrm{ml} ; 5 \%$ volume per volume (v/v) acepromazine in phosphatebuffered saline (PBS)] and perfused with $4 \mathrm{U} / \mathrm{ml}$ heparin in PBS. Cerebellae and spinal cords were dissected rapidly, the later separated into cervical and thoraco-lumbar regions, and placed into PBS containing freshly prepared $4 \%$ paraformaldehyde at room temperature, overnight, and embedded in paraffin. In some experiments, mice were directly perfused with $4 \%$ paraformaldehyde in PBS.

\section{Immunohistochemistry}

$W r / w r$ and $w t$ tissue sections were processed together, along with negative and positive 
controls. They were mounted onto slides, deparaffinized, hydrated and processed for immunohistochemistry (41). Slides were immersed in Target reagent and heated twice, for 3 min each at high power in an 800 watt commercial microwave oven. After the slides cooled down, the endogenous peroxide was blocked by $3 \% \quad \mathrm{H}_{2} \mathrm{O}_{2}$. Tissue slides were processed through an avidin-biotin blocking system, according to the manufacturer's instructions, and then placed in PBS. In preliminary experiments, we used human platelets as the positive control for the PAR-1C antibody.

All reagent incubations and washes were performed at room temperature. Normal blocking serum was then placed on slides for 10 min, and after a brief rinsing in PBS, primary antibodies were placed on the slides for 30 min. The slides were washed, then the biotinylated secondary antibodies, goat anti-rabbit (polyclonal antibodies), or horse anti-mouse (monoclonal antibodies) were placed on the tissue sections for $30 \mathrm{~min}$. After rinsing in PBS, the avidin-biotin-HRP complex reagent was added for $30 \mathrm{~min}$. The slides were washed and treated with the chromogen, 3,3'-diaminobenzidine, two times for $5 \mathrm{~min}$. Then, slides were rinsed in distilled $\mathrm{H}_{2} \mathrm{O}$, counterstained in Mayer's hematoxylin, dehydrated, and coverslips placed. The slides were visualized and photographed under an Olympus BX50 light microscope (Olympus, Melville, NY).

Controls were run for each sample of spinal cord tissue. Negative controls included replacement of the primary antibody with antibody diluent and the use of the same-species $\lg G$ isotype nonimmunized serum. Positive control antibodies included relevant neuronal (neuron specific enolase, NSE) and glial fibril- lary acidic protein (GFAP) cellular markers. For all studies, $w r / w r$ were always directly and simultaneously compared with their $w t$ littermates and at least three different individuals for each genotype were analyzed.

\section{In situ Hybridization (ISH)}

Five micron tissue sections of P21 mouse spinal cords were mounted onto Plus-Superfrost slides, air dried overnight at room temperature, and processed for in situ hybridization (40). Wr/wr and $w t$ samples were run at the same time and positive and negative controls were always included. The slides were routinely dewaxed, then hydrated with deionized water and placed into $3 \% \mathrm{H}_{2} \mathrm{O}_{2}$ for $10 \mathrm{~min}$ at room temperature. After a brief wash in $\mathrm{dH}_{2} \mathrm{O}$, the slides were placed into universal buffer (Research Genetics, Huntsville, AL). The tissues were digested with proteinase $\mathrm{K}$ for 10 min at $42^{\circ} \mathrm{C}$. The slides were thoroughly washed and then dehydrated in $100 \%$ alcohol for $1 \mathrm{~min}$. Each probe (Table 1) was diluted to $1.0 \mu \mathrm{g} / \mathrm{mL}$ in hybridization buffer and then heated for $5 \mathrm{~min}$ at $103^{\circ} \mathrm{C}$ in a microcentrifuge tube on a heat block. The probes were placed in a $42^{\circ} \mathrm{C}$ water bath until placement onto the tissues. $10 \mu \mathrm{l}$ of probe cocktail were added to the section and a coverslip was placed over the solution. The slides were then placed in a humid chamber and incubated at $42^{\circ} \mathrm{C}$ for $2 \mathrm{hr}$. After hybridization, the slides were immediately placed into a low-stringency wash $(2 \times$ SSC) for $5 \mathrm{~min}$, followed by a high stringency wash $(0.1 \times \mathrm{SSC})$ for $5 \mathrm{~min}$, both at $42^{\circ} \mathrm{C}$. Sequentially, slides were placed into universal buffer, then the avidin-HRP-biotin complex

Table 1. Probes used to detect PAR-1 mRNA

\begin{tabular}{|c|c|c|}
\hline \multicolumn{3}{|c|}{ Biotinylated DNA probes } \\
\hline Name $^{1}$ & Sequence & Vendor \\
\hline GAPDH & 5'- GAC GCC TGC TTC TCC TCC TTC TTG & Ransom Hill, CA \\
\hline poly d(T) & 5'- TTT TTT TTT TTT TTT TTT TTT TTT & Research Genetics, AL \\
\hline lac Z & 5'- CAC AGC GGA TGG TTC GGA TAA TG & Ransom Hill, CA \\
\hline PAR-1 & 5'- TTC ATT TTT СТC СТC СТC СТC СТC АTC C & Research Genetics, AL \\
\hline
\end{tabular}

\footnotetext{
${ }^{1}$ Oligonucleotide probes that localized receptor through in situ hybridization experiments or served as positive (GAPDH) or negative (poly $\mathrm{d}(\mathrm{T})$ or lac Z) controls.
} 
was added for $\mathrm{l} \mathrm{hr}$ at room temperature. The slides were washed and then exposed to 3-3' diaminobenzidine twice, for $5 \mathrm{~min}$ each time, at room temperature. The slides were routinely stained with hematoxylin and then dehydrated, cleared in xylene, covered in Permount and photographed on an Olympus BX50 light microscope.

The positive controls included two biotinylated mRNA oligonucleotide probes; one specific to glyceraldehyde-3-phosphate dehydrogenase (GAPDH) mRNA and the other a positive control, a poly-d(T) probe, which hybridized to poly(dA) tails on mRNAs. The negative controls included the absence of the probe in the probe cocktail and a biotinylated probe specific to lac $\mathrm{Z}$ operon mRNA.

\section{Terminal Deoxynucleotidyl Transferase (TdT) Mediated Biotin-d-UTP Nick End Labeling (TUNEL) of DNA}

$W r / w r$ and $w t$ littermate cervical spinal cords were frozen and cryostat cut into $10 \mu$ sections, fixed with formalin, permeabilized with proteinase $\mathrm{K}$, and the ends were labeled with biotin-14-dATP as described (42). TUNEL positive nuclei were visualized after incubation with HRP conjugated to streptavidin and diaminobenzidine (DAB), according to manufacturer's recommendations, and additional staining with neutral red.

\section{Reverse Transcription Polymerase Chain} Reaction (RT-PCR)

RNA Isolation. For embryonic specimens, timed-dated pregnancies were established by placing two females in a male's cage at 1900 hours and observing for a vaginal plug at 0800 hours, at which time gestation was E0.5 days. At designated gestational times, pregnant females were anesthetized by $\mathrm{CO}_{2}$ narcosis and the uterus quickly opened, embryos removed, placed in cold PBS in a sterile Petri dish, and genotypes established. Cervical and lumbar spinal cord regions were dissected and kept separate, flash-frozen in liquid nitrogen and stored at $-80^{\circ} \mathrm{C}$ for further use. Frozen tissue samples (cerebellae, cervical, or lumbar spinal cord sections) were powdered using liquid nitrogen and a mortar and pestle. Then, $1 \mathrm{ml}$ of Tri Reagent was added to approximately $40 \mathrm{mg}$ of crushed sample and homogenized with a Polytron (on ice, three bursts of 2 sec each). The mix was incubated at room temperature for
$5 \mathrm{~min}$, followed by the addition of $0.2 \mathrm{ml}$ of isoamyl alcohol-free chloroform, manual inversion for $15 \mathrm{sec}$, and further incubation at room temperature for $15 \mathrm{~min}$. After centrifugation at $12,000 \times g$ for $15 \mathrm{~min}$ at $4^{\circ} \mathrm{C}$, the aqueous phase was separated and RNA precipitated for $10 \mathrm{~min}$ at room temperature with $0.5 \mathrm{ml}$ of isopropanol. Centrifugation at $12,000 \times g$ for 10 min at $4^{\circ} \mathrm{C}$ resulted in a pellet that was subsequently washed in $1 \mathrm{ml}$ of $75 \%$ ethanol $\left(-20^{\circ} \mathrm{C}\right)$. The pellet was isolated after centrifuging at $7500 \times g$ for $5 \mathrm{~min}$ at $4^{\circ} \mathrm{C}$ and removal of the supernatant. The RNA pellet was desiccated under vacuum, resuspended in diethylpyrocarbonate (DEPC)-treated $\mathrm{H}_{2} \mathrm{O}$, quantitated by spectrophotometry $\left(\mathrm{A}_{260}\right.$ and $\left.\mathrm{A}_{280}\right)$, and stored at $-70^{\circ} \mathrm{C}$.

Total RNA isolated from wobbler and wt littermate spinal cords was used to determine the presence of PAR-1 message by RT-PCR as follows: $0.5 \mu \mathrm{g}$ of RNA was incubated in $20 \mu \mathrm{l}$ of $50 \mathrm{mM} \mathrm{KCl}, 10 \mathrm{mM}$ Tris $\mathrm{HCl}, \mathrm{pH} 8.3$, $1.5 \mathrm{mM} \mathrm{MgCl}{ }_{2}, 10 \mathrm{mg} / \mathrm{ml}$ gelatin, $1 \mathrm{mM}$ dNTP, $200 \mathrm{U}$ reverse transcriptase, and $0.5 \mu \mathrm{M}$ downstream, reverse primer (5'-GCCATCACCC AAATGACCAC) for $10 \mathrm{~min}$ at room temperature; followed by $30 \mathrm{~min}$ at $42^{\circ} \mathrm{C}, 5 \mathrm{~min}$ at $95^{\circ} \mathrm{C}$, and finally cooled to $4^{\circ} \mathrm{C}$. The cDNA produced in this $\mathrm{RT}$ reaction was then amplified under similar buffer conditions, except the volume was $100 \mu \mathrm{l}$, the dNTP concentration was $0.2 \mu \mathrm{M}$, and $0.5 \mu \mathrm{M}$ upstream, forward primer (5'-CTTGCTGATC GTCGCCCTCG) was added. The PCR was begun at $98^{\circ} \mathrm{C}$ for $10 \mathrm{~min}$, followed by the addition of $2.5 \mathrm{U}$ Taq polymerase, and 30 cycles of $95^{\circ} \mathrm{C}$ for $1 \mathrm{~min}, 60^{\circ} \mathrm{C}$ for $1 \mathrm{~min}$, and $72^{\circ} \mathrm{C}$ for $7 \mathrm{~min}$. Negative control pairs lacking only RT or lacking only template were included in each run and did not produce bands.

Co-AMPLIFICATION. PAR-1 and GAPDH cDNAs were generated simultaneously from the same reaction with $0.5-1.0 \mu \mathrm{g}$ RNA in a $20 \mu \mathrm{l}$ reaction containing $0.5 \mu \mathrm{M}$ PAR-1 reverse primer, $0.5 \mu \mathrm{M}$ GAPDH reverse primer (5'-ATCCACGACGGACACATTG), and the same reaction conditions for reverse transcription as above. Each standard $50 \mu \mathrm{l}$ PCR consisted of $2.5 \mu \mathrm{l}$ cDNA product, $0.5 \mu \mathrm{M}$ of PAR-1 forward and reverse primer, and $0.5 \mu \mathrm{M}$ GAPDH forward (5'-GGCAAATTCAACGGCACAG), and reverse primer. All products were viewed on a $3 \%$ Metaphor agarose gel stained with ethidium bromide. 


\section{Quantitative RT-PCR (qRT-PCR)}

Mimic RNA Synthesis. A subclone, in which a deletion was introduced (pRMS11) and utilized to synthesize control/mimic RNA, was generated (36) from a pSport rat PAR-1 cDNA clone, provided by the laboratory of Marschall Runge, M.D., Ph.D (University of Texas, Medical Branch, Galveston, TX). Mimic RNA for this experiment was produced from pRMS 11 linearized by digestion (with HindIII), transcribed, and quantified spectrophotometrically at 260 and $280 \mathrm{~nm}$ as described (36).

Reverse transcription reactions were set up using dilutions of the generated mimic PAR-1 RNA (36), together with varying amounts of endogenous RNA as the templates in the same reactions. This coamplification, using the same primers and reaction conditions, allowed for the quantitation of the native PAR-1 message, relative to the mimic. $20-\mu \mathrm{l}$ reactions were set up and PCR was performed using $10 \mu \mathrm{l}$ of the generated cDNA. The products were visualized on a 3\% Metaphor agarose gel stained with ethidium bromide.

\section{Genotyping}

In our NZB colony, the $\mathrm{G}^{\mathrm{NZB}}$ allele that is adjacent to the wobbler locus on mouse chromosome 11 (15), produced a 188-bp amplification product when DNA was amplified with 5'AGCTTTGGAG ACAACAATTAGATC and 5'GGATGGGGA AATGGTGGTACA specific glns primers (18). The glns locus in the NFR/N strain $\left(\mathrm{G}^{\mathrm{NFR}}\right)$ yielded a 162-bp product, as did other non-NZB strains, such as CDl (not shown). DNA was extracted from $1 \mathrm{~cm}$ tail snips or small liver samples (in the case of embryos) and purified with a Qiagen (Valencia, CA) tissue DNA kit. PCR amplification was performed with $\sim 50 \mathrm{ng}$ DNA in $100 \mu \mathrm{l}$ reactions with $0.5 \mu \mathrm{M}$ each primer, IX PCR reaction mix, and $200 \mu \mathrm{M}$ each dNTP. The DNA was initially denatured at $98^{\circ} \mathrm{C}$ for $10 \mathrm{~min}$, then $2.5 \mathrm{U}$ of Taq polymerase was added at $90^{\circ} \mathrm{C}$, followed by $30-35$ cycles of denaturation at $95^{\circ} \mathrm{C}$, for $1 \mathrm{~min}$, annealing at $55^{\circ} \mathrm{C}$, for $1 \mathrm{~min}$, and extension at $72^{\circ} \mathrm{C}$ for $30 \mathrm{sec}$. Products were visualized by electrophoresis in 3\% Metaphor (FMC, Rockland, ME) agarose gels and staining with ethidium bromide. For rapid genotyping, we extracted DNA from small, homogenized samples that were incubated with detergent and proteinase $\mathrm{K}$ for $15 \mathrm{~min}$ at $55^{\circ} \mathrm{C}$ and amplified with 15 sec denaturation, an- nealing, and extension steps according to Arce et al. (43).

\section{Thrombin Amidolytic Assay}

Using the thrombin-preferred chromogenic substrate, S-2238 (D-Phe-Pip-Arg- $p$-nitroanilide) (44), thrombin activity was measured in conditioned medium of primary murine spinal cord astrocytes from 28-day-old $w t$ and $w r / w r$ mice (37), kept 8 days in vitro, with the final 24 $\mathrm{hr}$ in serum-free condition. The release of $p$-nitroanilide was measured at $410 \mathrm{~nm}$ as previously described (45).

\section{SDS-PAGE and Western Blots}

Wobbler and $w t$ spinal cords were removed as above and cervical cord segments dissected, blotted dry, weighed and homogenized in a 1:10 ratio (weight per volume, w/v) of $50 \mathrm{mM}$ Tris HCI (pH 7.4) containing $250 \mathrm{mM}$ sucrose, $10 \mathrm{mM}$ EDTA, $150 \mathrm{mM} \mathrm{NaCl}$ and $1 \%$ Triton $\mathrm{X}-100$ Cord extracts were centrifuged at $15,000 \times \mathrm{g}$ for $15 \mathrm{~min}$ at $4^{\circ} \mathrm{C}$, and the supernatants were collected and analyzed for protein using the BCA method. Samples, ranging from 5-25 $\mu \mathrm{g}$, were applied to a precast $12 \%$ SDS-PAGE under reducing conditions and, then, transferred to PVDF membranes and blocked with $10 \%$ nonfat dry milk and $0.1 \%$ Tween 20 in PBS, as previously described (45). PVDF membranes were treated with a 1:500 dilution of antibody PAR-1C in 3\% nonfat dry milk and $0.1 \%$ Tween 20 in PBS, followed by HRP-conjugated goat anti-mouse IgG at the same conditions, and visualized with the ECL kit.

\section{Statistics}

Comparison of PAR-1 mRNA between $w r / w r$ and $w t$ littermates was performed with a twotailed, unpaired Student's $t$-test using StatView 4.0 software (Abacus Concepts, Berkeley, CA).

\section{Results}

Release of Thrombin from Spinal Cord Astrocytes in Culture

Prothrombin is expressed in both developing central (46) and peripheral nervous systems $(47,48)$, and after neural injury (32). In the brain, astrocytes synthesize and secrete prothrombin $(49,50)$. Therefore, we first addressed the possible pathologic interactions between 
motor neuron cell death and the prominent astrocytosis in $w r / w r$ mice by analyzing thrombin amidolytic activity in young adult (28-day-old) spinal cord astrocytes after 8 days in vitro, with a final $24 \mathrm{hr}$ in serum-free conditions. Conditioned media (CM) was collected from $w r / w r$ and $w t$ littermate spinal cord astrocyte primary cultures ( 8 days in vitro). Amidolytic activity was assayed with a thrombin-preferred chromogenic substrate (45) and further confirmed by inhibition with hirudin, the thrombin-specific inhibitor from the leech (51). Wr/wr glial cells released a 2 -fold greater amount of thrombin amidolytic activity $(7.9 \pm 0.5 \mathrm{U} / \mathrm{mg}$ protein), compared with wt astrocytes $(4.5 \pm 0.7$ $\mathrm{U} / \mathrm{mg}$ protein; $p=0.015$ ), and more than $90 \%$ of this activity was inhibited by $100 \mathrm{nM}$ hirudin. This allowed us to postulate that in- creased protease-ligand from astrocytes might interact with greater PAR-1 expression in motor neurons (36).

\section{Phenotypic Features and Reactive Astrocytosis}

Unlike earlier reports in the literature (22), $w r / w r$ mice in our colony showed the first clinical symptoms and neurological abnormalities prior to $\mathrm{P} 2 \mathrm{l}$. Wr/wr mice were significantly smaller than their $w t$ littermates and this was detected by P15 when these mice first developed atrophy of forelimb muscles and shaking ("wobbling") of the body. If left undisturbed, they died by 3 to 6 months of age.

We localized GFAP in $w r / w r$ spinal cords using immunohistochemistry with a commercial polyclonal antibody to GFAP and our re-

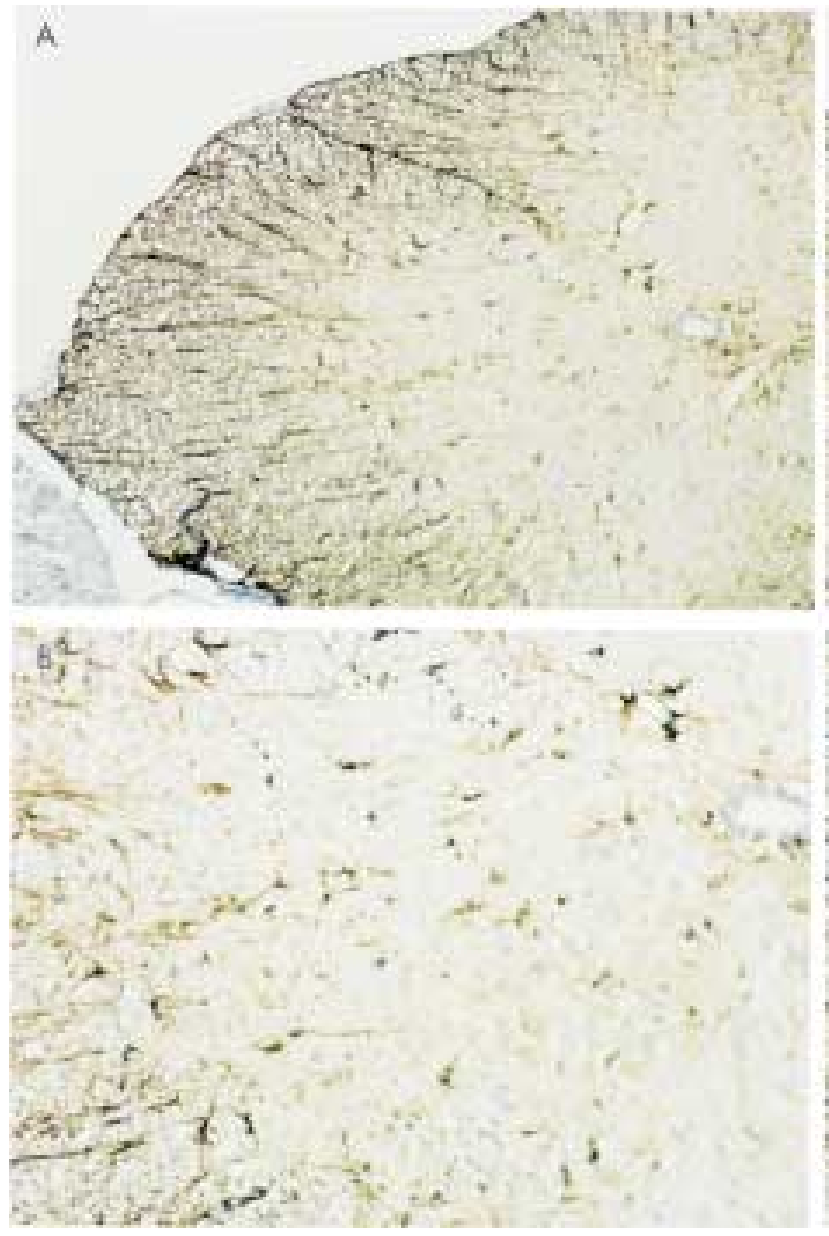

Fig. 1. Glial fibrillary acidic protein (GFAP) in mouse spinal cords. GFAP immunolabeling in the $w t$ spinal cord (A) at $150 \times$ and (B) at $800 \times$ magnification. Greater labeling appear in the white matter, with lack of significant GFAP immunolabeling in the gray matter. $W r / w r$ samples $[(C)$ at $150 \times$ and

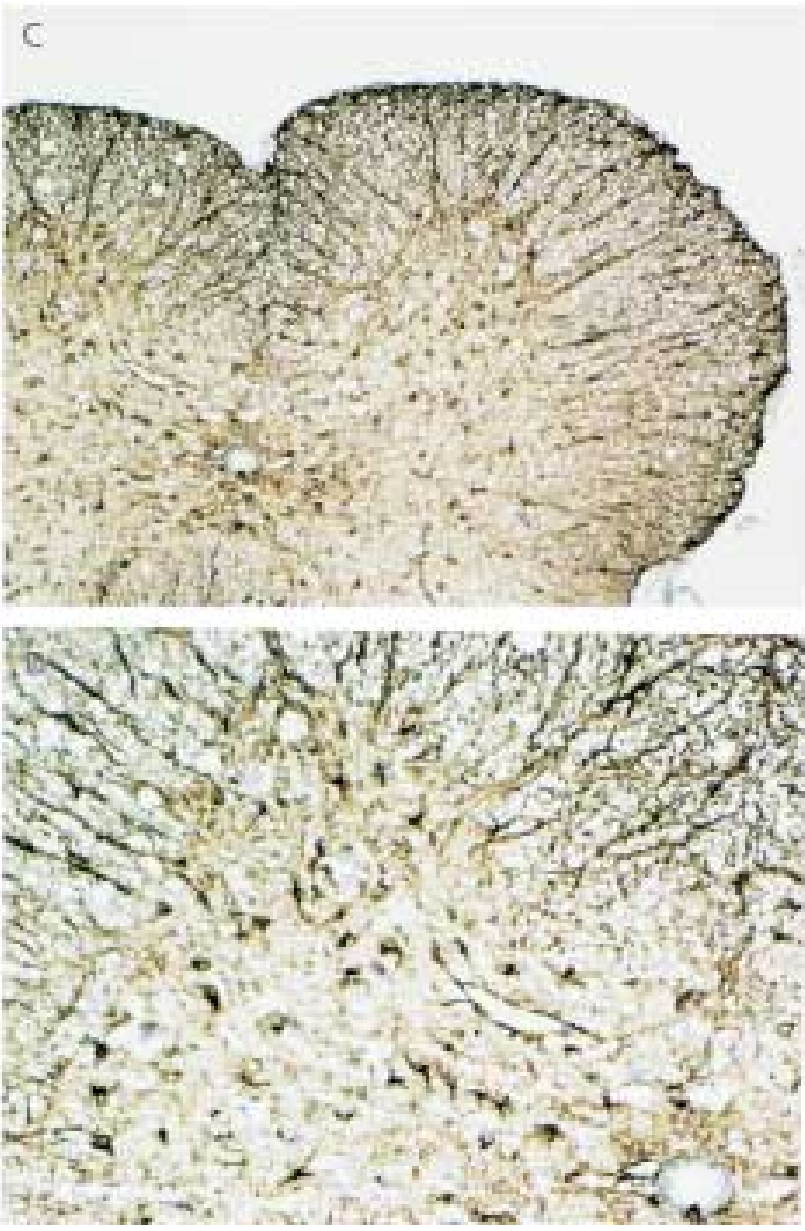

(D) at $300 \times$ magnification] demonstrate markedly increased GFAP immunolabeling in the wobbler spinal cord, which is particularly intense in the gray matter. All figures display the dorsal aspect at the top. 
sults confirmed two previous reports indicating that overgrowth of astrocytes accompanied motor neuronal degeneration in wobbler mice $(37,52)$. Basal levels of GFAP in the white matter and extremely low levels of GFAP were detected in the gray matter of normal $w t$ littermate spinal cords (Figs. 1A and B). In stark contrast, a marked increase in GFAP immunolabeling was found not only in the white, but also in the gray, matter of the wobbler spinal cord (Figs. IC and D).

\section{PAR-1 Western Blots of wt and wr/wr} Spinal Cord Extracts

Using a rabbit polyclonal anti-mouse PAR-1 (PAR-1C) antibody, we performed Western transfers with protein extracts of both $w t$ and $w r / w r$ mouse spinal cords and found that it recognized in both an $\sim 50 \mathrm{kDa}$ polypeptide (53,54; Fig. 2). This band was similar in $\mathrm{Mr}$ to that previously reported for mouse fibroblast PAR-1 (53). Previous studies with model and primary motor neurons in culture, using a different antibody (R49) made against residues $36-49$ of the human PAR-1 spanning the thrombin cleavage site, recognized a similar-sized, $\sim 50 \mathrm{kDa}$ protein (54). As seen in the Western blots using anti-PARIC antibody, in addition to the $\sim 50 \mathrm{kDa}$ band, we detected an additional band at lower Mr ( $\sim 45$ kDa; Fig. 2). No other bands

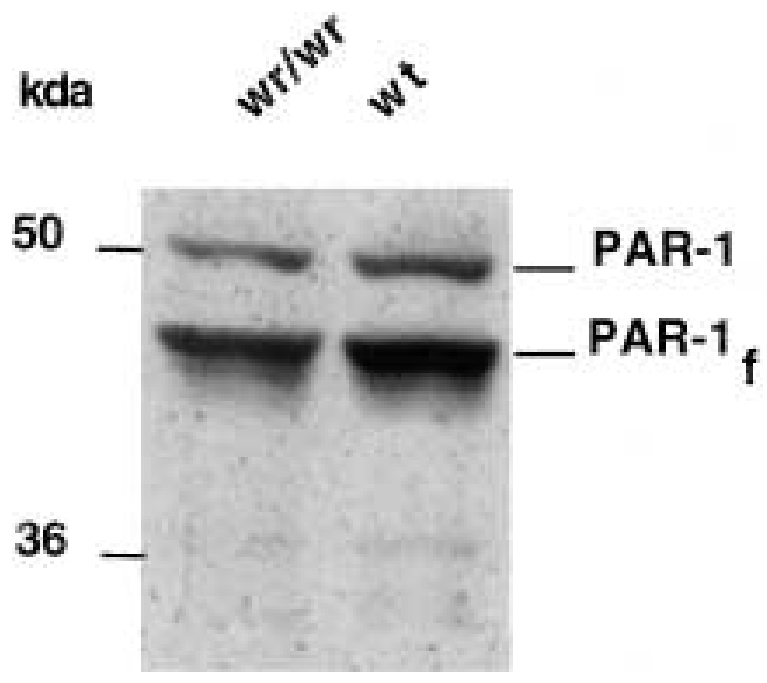

Fig. 2. Western immunoblot of PAR-1 in postnatal day 21 (P21) mouse spinal cord extracts. Both $w r / w r$ and $w t$ extracts contain $\sim 54 \mathrm{kDa}$ immunoreactive protease-activated receptor 1 (PAR-1). Both also have an additional band (PAR- $\mathrm{l}_{\mathrm{f}}$ ) at $\sim 45 \mathrm{kDa}$, potentially a proteolytic fragment of PAR-1. were visible. The size was similar in $\mathrm{Mr}$ to that found in CM of NSC19 motor neurons treated with $\alpha$-thrombin using the R49 antibody (54). Cleavage of PAR-1 has not been examined previously in tissue extracts. However, in our studies, evidence for partial cleavage for at least some population of PAR1 molecules was found consistently in all wobbler spinal cord extracts (we labeled this fragmented band at $\sim 45 \mathrm{kDa}$, PAR- $\mathrm{l}_{\mathrm{f}}$ ), but less in $w t$ spinal cord samples.

Using the PAR-1C antibody, we then performed immunohistochemistry and observed that PAR-1 primarily stained large ventral horn motor neurons in spinal cords of 28-day-old $w t$ mice (Figs. 3A and B). Faint staining was observed over dorsal horn neurons, as well as on smaller interneurons within the ventral horns. There was little reaction found in the white matter tracts laterally or anteriorly. In stark contrast to motor and other neurons, very faint staining of non-neuronal cells was seen in either the gray or white matter of the cord. Slightly greater staining was found in sections of $w t$ cerebellum (not shown).

In contrast to the fine, homogeneous membrane staining in $w t$ mice, PAR-1 was found to be increased in the 28-day-old $w r / w r$ cervical cord (Figs. 3C and D), where we confirmed (Fig. 1) that the degeneration was greatest $(14,22)$. The increased PAR-1 immunostaining in $w r / w r$ spinal cords was present throughout the cervical cord gray matter in both dorsal, as well as ventral, horns. This was in contrast to the white matter, which was clearly outlined from it, where axons did not stain either in $w t$ or in $w r / w r$ mice (Fig. 3A). The most dramatic cellular findings were in the large alpha motor neurons of the ventral horn. It is these cells that bear the brunt of the degeneration in the wobbler mutation $(14,22)$. By this technique, we found that virtually all remaining motor neurons had markedly increased levels of PAR-1 protein. Considerably less staining, similar to the intensity range of controls, was seen in thoracolumbar sections of $w r / w r$ mouse spinal cords, as well as in thoracolumbar regions of littermates (not shown), where a number of large neuronal profiles that were consistent with motoneurons were not stained by the anti-PAR- 1 antibody.

\section{PAR-1 Gene Expression}

Normal rat motor neurons were recently shown to contain increased amounts of PAR-1 mRNA 

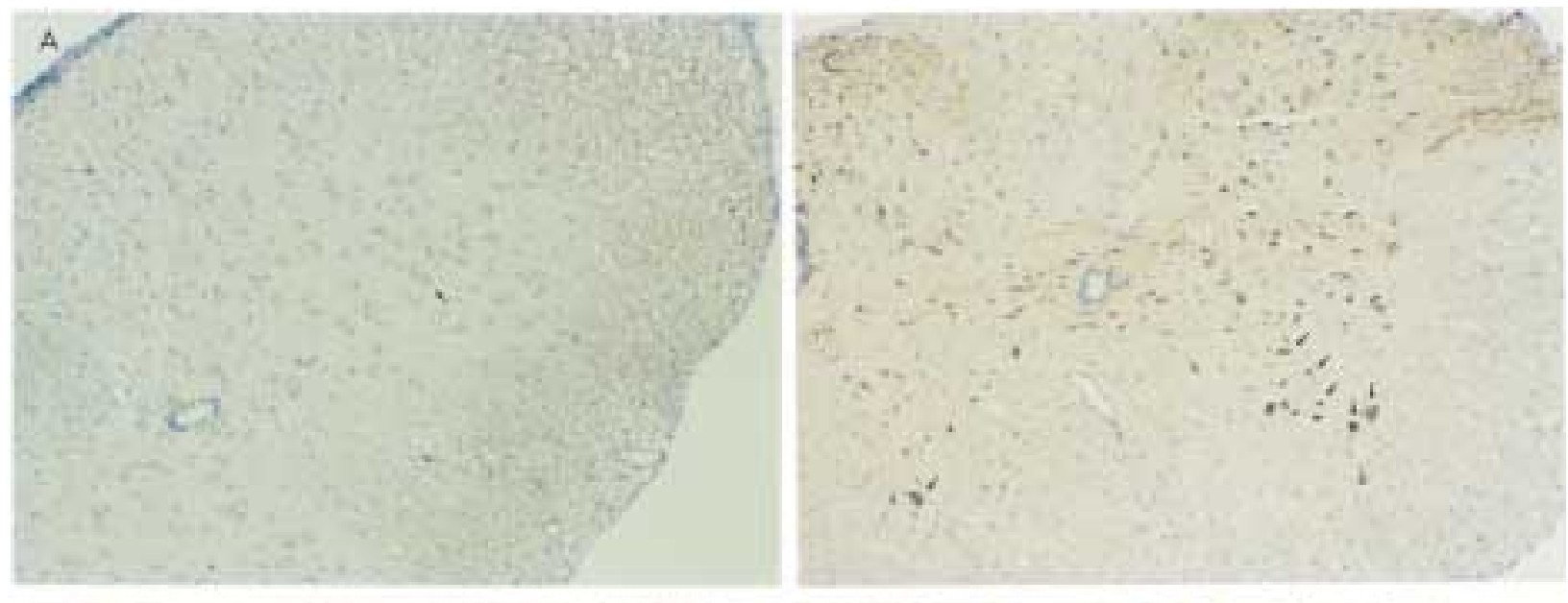

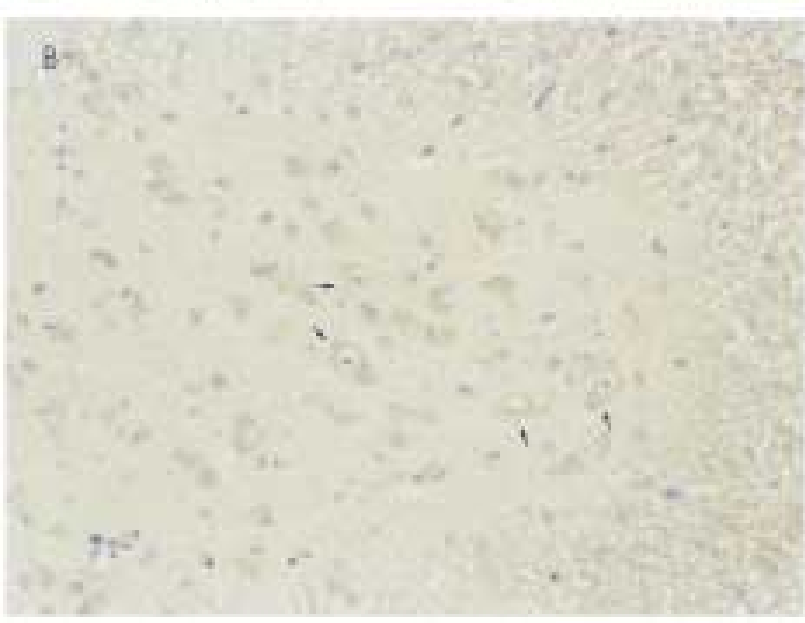

Fig. 3. Wobbler spinal cords display increased levels of PAR-1 antigen. Anti-mouse (PAR-1) antibody detects basal levels of the G-protein-coupled PAR-1 on membranes and in cytoplasm of large, $w t$ alpha motor neurons (arrows) in the ventral cord. (A) $150 \times$ and (B) $300 \times$ magnification. Loss of motor neurons, as well as cervical cord degeneration (pyknosis), is apparent in the wobbler spinal cord

by in situ hybridization compared with other neuronal populations (55). Pathologic increase in PAR-1 expression might make these motor neurons even more sensitive to thrombin's effects, whether locally produced $(32,46)$ or passing a bridged blood-brain or spinal cord barrier (28). Since many of the remaining motor neurons in $w r / w r$ spinal cords that stained with anti-PAR-1 antibody appeared somewhat shrunken and pyknotic, we sought confirmation of increased expression at the mRNA level. When we previously performed RT-PCR to subplateau levels, the PAR-1 message was clearly detectable in $w t$ littermate, as well as wobbler, spinal cords (36). However, greater

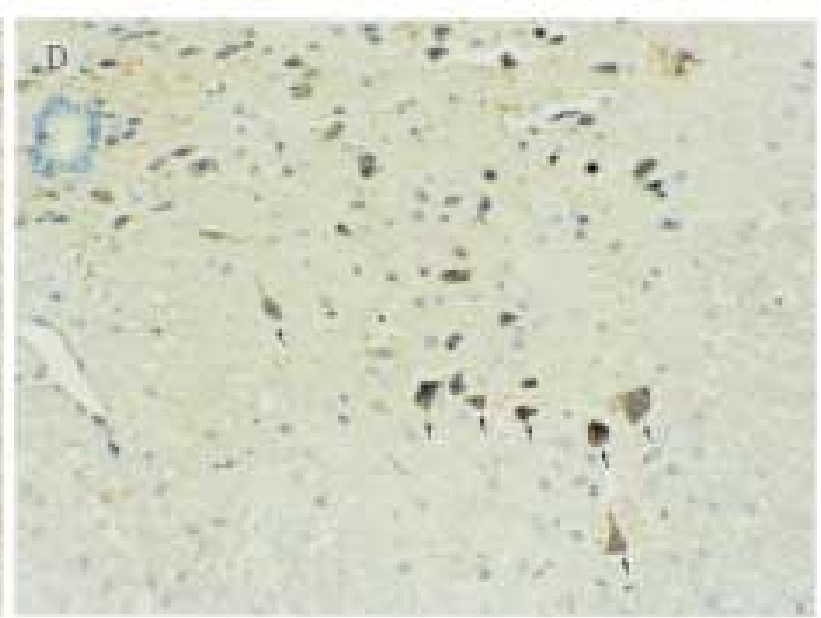

and PAR-1 levels are dramatically elevated, as identified by the intense PAR-1 immunoreactivity in the large alpha motoneurons (arrows). (C) $150 \times$ and (D) $300 \times$ magnification. In lumbar regions of $w t$ and $w r / w r$ samples, PAR-1 did not stain significantly. Such results are identical in each of five $w r / w r$, compared with four wt littermates.

amplified product was found in matched RNA samples obtained from adult $w r / w r$ cervical cord RNA, compared with wt (Fig. 4A). Slightly greater PAR-1 mRNA, again semiquantitative, was detected in $w r$ cerebellar RNA, compared with normal RNA.

Given the semi-quantitative RT-PCR increase in PAR-1 mRNA in $w r / w r$, compared with $w t$, littermates (36), we compared the PAR-1 mRNA directly to GAPDH mRNA levels in the same samples (Fig. 4B), confirming previous results with other litters (36). When cotranscribed and amplified with primers that also amplify the sequence of the GAPDH gene, we obtained dual products from these two primer pairs at the 

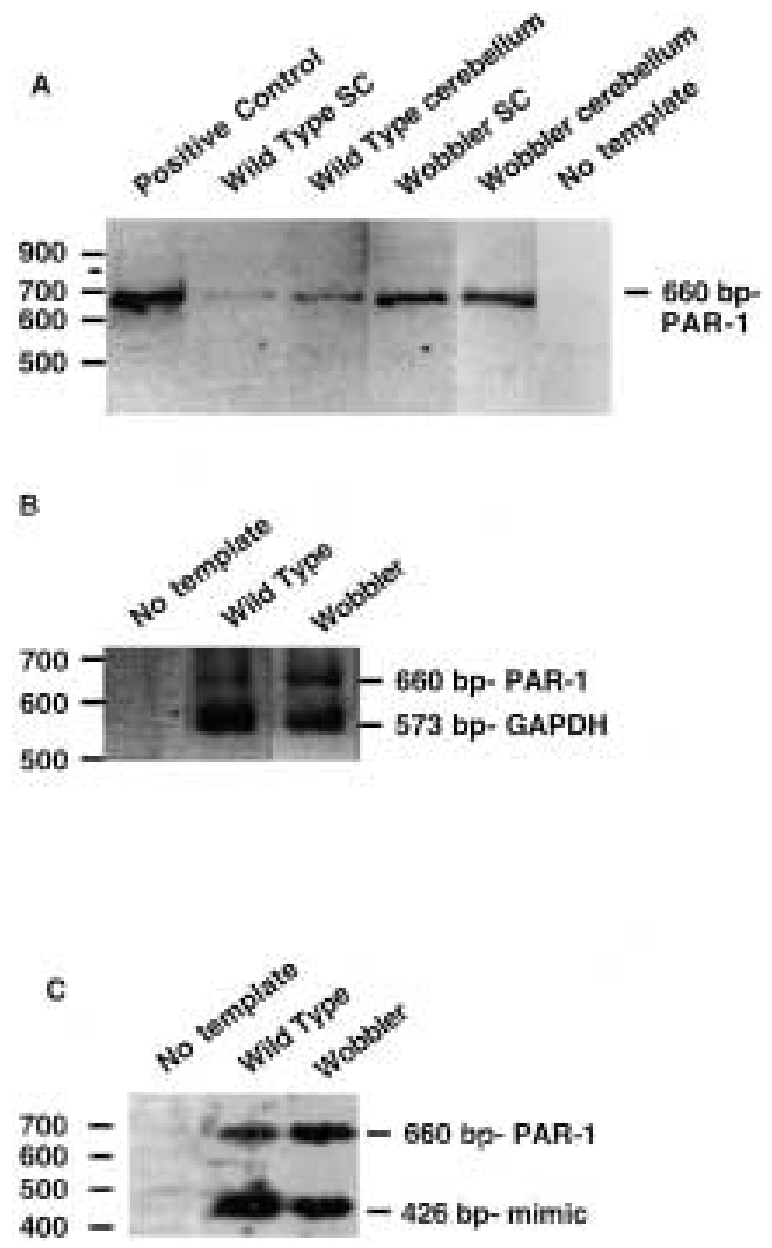

Fig. 4. PAR-1 message in wobbler and wt cervical spinal cords and cerebellae. (A) reverse transcription polymerase chain reaction (RT-PCR) amplification of PAR-1-specific sequence shows the appropriately sized product $(660 \mathrm{bp})$ derived from PAR-1 message. (B) RT-PCR analysis of $w r / w r$ spinal cord PAR-1 relative to GAPDH. PAR-1 mRNA is increased in homozygote $w r / w r 2.8 \times$ relative to cotranscribed and amplified GAPDH mRNA (573 bp). (C) Quantitative RT-PCR analysis of $w r / w r$ spinal cord PAR-1. Elevated levels of PAR-1 mRNA are present in homozygote $w r / w r$, compared with $w t$ littermates ( 5 -fold), based on the relative ratios of endogenous product $(660 \mathrm{bp})$ to mimic PAR-1 product $(426 \mathrm{bp})$ in each reaction. Total RNA (1 $\mu \mathrm{g}$ ) was mixed with $0.5 \mathrm{pg}$ PAR-1 mimic RNA for the wild type sample or 1 pg mimic RNA for the $w r / w r$ sample, prior to reverse transcription and amplification.

appropriate sizes. The 660-bp PAR-1 product appeared above the 573-bp GAPDH amplimer and, when the relative intensities of the bands were quantified, the results showed that the PAR-1 message was elevated $\sim 3$-fold, relative to GAPDH in the wobbler spinal cord, compared with the wt littermate (Fig. 4B; Table 2). Since there was some reproducible attenuation of the GAPDH amplimer in the wobbler spinal cord extracts, we tested endogenous RNAs from $w r / w r$ and $w t$ littermate spinal cords with in vitro generated control PAR-1 RNA.

\section{Quantitative RT-PCR ( $q R T-P C R$ )}

Using authentic and mimic templates described in "Material and Methods" and previously detailed (36), we confirmed the significant increases in PAR-1 mRNA levels. The 237-bp deletion we generated in a PAR-1 cDNA (subcloned into the pCR2.1 transcription vector) enabled qRT-PCR to accurately determine the PAR-1 mRNA content in each spinal cord. This approach previously allowed us to quantify levels of prothrombin mRNA in developing mouse muscle (47) and, recently, in rat spinal cord (Citron et al., submitted). With the introduction of titrated amounts of control, mimic transcript into the RT reaction prior to amplification, we were able to estimate the copy number of PAR-1 mRNA present in the $w r / w r$ spinal cords, compared with wt littermates and, more directly, to measure the increased levels of PAR-1 message. As seen in Figure 4C, relatively more PAR-1 message, relative to specific mimic RNA added, was present in wr/wr RNA samples. From calculations in Table 2, normalization to input templates and relative product yields, indicated that the PAR-1 mRNA was greater than 5 -fold higher, compared with the $w t$ littermate $(p=0.018)$. Of interest, correlating again with the burden of degeneration of motor neurons and increased GFAP staining (astrocytosis), the increase in PAR-1 mRNA measured by QRT-PCR was greatest in the wobbler cervical spinal cord, when compared with both cerebellum and thoracolumbar spinal cord (Fig. 5).

\section{PAR-1 mRNA Localization in wt and wr/wr Spinal Cords}

In situ hybridization experiments produced unambiguous negative controls, such as the biotinylated lacZ operon probe (Fig. 6E,F); whereas, all positive controls, such as the poly $\mathrm{d}(\mathrm{T})$ biotinylated probe, labeled consistently (data not shown). These hybridizations showed that PAR-1 mRNA expression levels were consistent with both the protein and RTPCR data. The labeling pattern in the $w t$ spinal cord was uniform and homogenous (Fig. 6A). Although we found minimal nuclear labeling, 
Table 2. Quantitative analysis of PAR-1 in P28 $w r / w r$ and $w t$ spinal cord

\begin{tabular}{llll}
\hline Strain & Littermate $(w t)$ & wr/wr & $\begin{array}{c}\text { Ratio } \\
w r / w r: w t\end{array}$ \\
\hline GAPDH internal control & & & 2.8 \\
PAR-1/GAPDH & 0.13 & 0.37 & 5.8 \\
PAR-1 mimic internal control copies & $1.04 \times 10^{5} \pm 3.4 \times 10^{4}$ & $5.99 \times 10^{5} \pm 1.5 \times 10^{4}$ & \\
PAR-1 mRNA/mg wet cord & & &
\end{tabular}

Prevalence of PAR-1 mRNA was compared with in vitro transcribed, control, mimic transcript to determine numbers of PAR1 mRNA molecules. The values are means \pm S.D. of three different $w r / w r$ and three $w t$ littermates (with $p<0.02$ in each case).

with negative nucleoli, there was a more defined area of perinuclear labeling. Non-neuronal cells (astrocytes and oligodendroglia) did not la-bel significantly with the PAR-1 oligoprobe (Fig. 6B).

In clear contrast to $w t$ littermates, the labeling pattern in wobbler spinal cords detectable by ISH was strikingly different, since it was markedly heterogeneous and nonuniform (Fig. 6C). In addition to increased perinuclear labeling for PAR-1 mRNA in motor neurons, the nucleoplasm labeled intensely (Fig. 6D). Neurons in $w r / w r$ cords labeled similar in pattern to $w t$ neurons and large motor neurons displayed prominent PAR-1 mRNA labeling (arrowheads). However, the intensity of labeling was much greater and was restricted to the largest neurons in the ventral and, to a lesser extent,

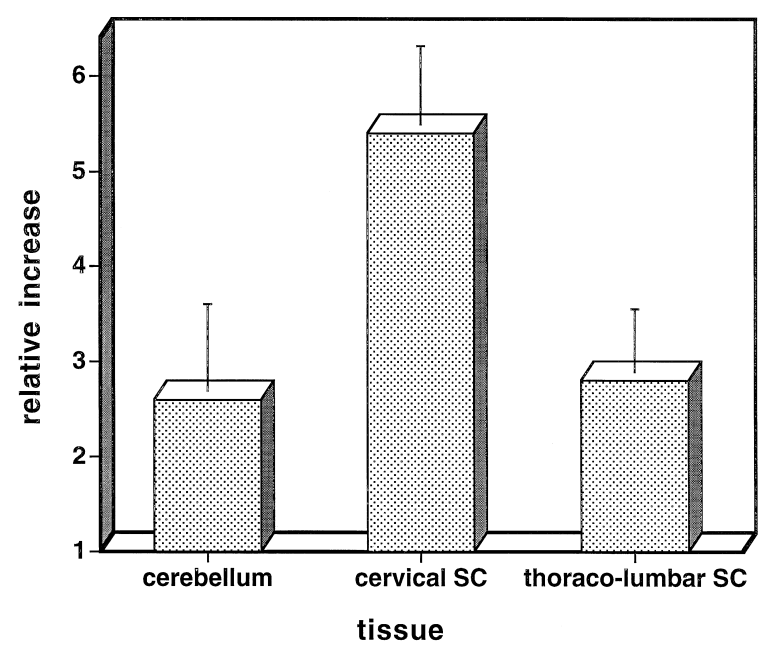

Fig. 5. PAR-1 mRNA is elevated in cervical spinal cord. Quantitative RT-PCR analysis reveals, relative to littermate samples, the most significant increase $(p<0.05)$ in the PAR-1 message level in the cervical region of the wobbler spinal cord. $(n=3$, values indicate means \pm S.E.M. $)$ dorsal, horns. At higher magnification the labeling was aggregated and overlaid motor neuron nuclei. This abnormal motor neuron labeling was most intense in the cervical regions (Fig. 3), compared with thoracolumbar segments, as we had found for immunohistochemistry. Surprisingly, despite the increase in reactive astrocytes, their increased GFAP, and the PAR-1 increased by qRT-PCR, this increase was not detected in astrocytes by in situ hybridization.

\section{Mode of Cell Death in wr/wr Mice}

We next attempted to determine the type of cell death occurring in the wobbler cervical spinal cord regions. Examination of in situ nuclear DNA fragmentation in the earliest phenotypically apparent wobbler homozygotes revealed dramatic TUNEL-positive nuclei, indicative of apoptotic fragmentation as shown in Figure 7. The TUNEL-positive cells were located primarily in the ventral horn and exhibited the large size, large nucleus, and other characteristics of motor neuron morphology. Of interest, in later $w r / w r$ spinal cords $(>\mathrm{P} 28)$, the percentage of apoptotic neurons in the ventral horns decreased significantly and the rapid decline in the number of motor neurons appeared to slow down (not shown). Spinal cords isolated from age-matched controls never displayed this labeling (Fig. 7). This suggested developmental regulation of postnatal apoptosis and raised the question as to when up-regulation of PAR-1 mRNA occurred in $w r / w r$ spinal cords.

\section{Developmental Regulation of PAR-1 Expression in wr/wr Spinal Cords}

Having confirmed our previous finding of the increase in PAR-1 expression in 28-day-old 

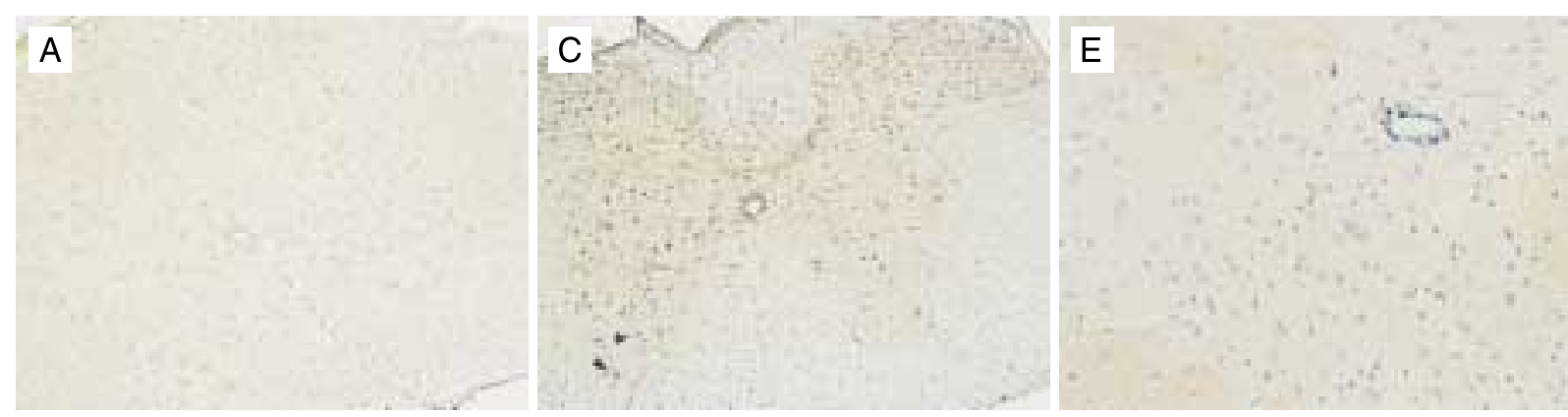
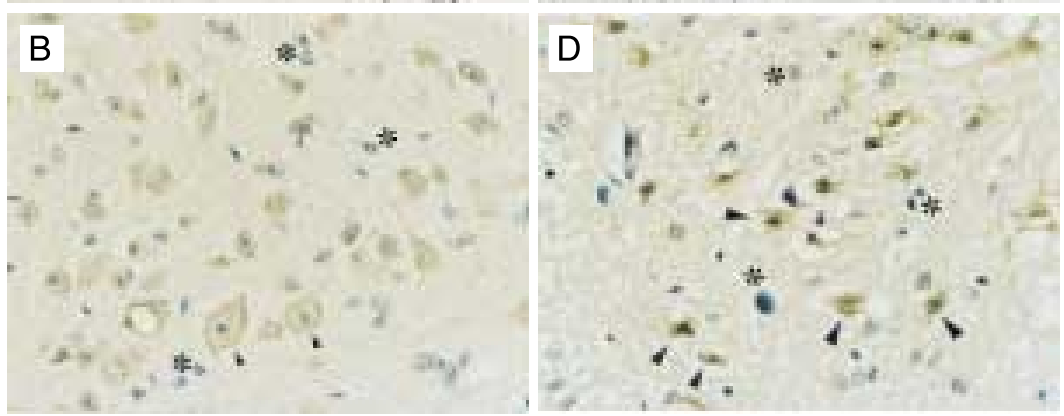

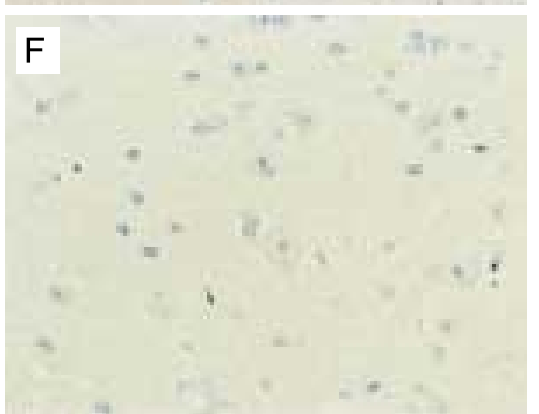

Fig. 6. In situ hybridization with biotinylated PAR-1 oligonucleotide mRNA probe. Micrographs (A) at $150 \times$ and (B) at $600 \times$ magnification, indicate basal levels of PAR-1 mRNA in the motor neurons (arrowheads) of $w t$ cervical spinal cord. Note the perinuclear, cytoplasmic pattern of labeling, lack of labeling of the nucleolus and diffuse labeling in the nucleoplasm. Astrocytes (asterisks) do not stain. Micrographs (C) at $150 \times$ and (D) at $600 \times$ magnification of $w r / w r$ cervical cord show mark

phenotypic $w r / w r$ mice (36), this prompted us to question when this overexpression occurred in their development. By postnatal day 21 , the homozygous wobbler mouse phenotypically had lost significant motor function in the forelimb overexpression of PAR-1 message, which completely fills motoneurons (arrowheads) and overlies nucleus and nucleolus. Despite this, little or no PAR-1 mRNA can be detected even in wr/wr astrocytes (asterisks). As a negative control, in situ hybridization with biotinylated lac Z mRNA oligonucleotide probe did not produce any detectable hybridization in the spinal cords at $300 \times(\mathrm{E})$ and $600 \times(F)$ magnification.

regions and motor neurons had been lost preferentially from the cervical region of the spinal cord (22). To understand the processes involved in the loss of these motor neurons and to determine whether they shared any features

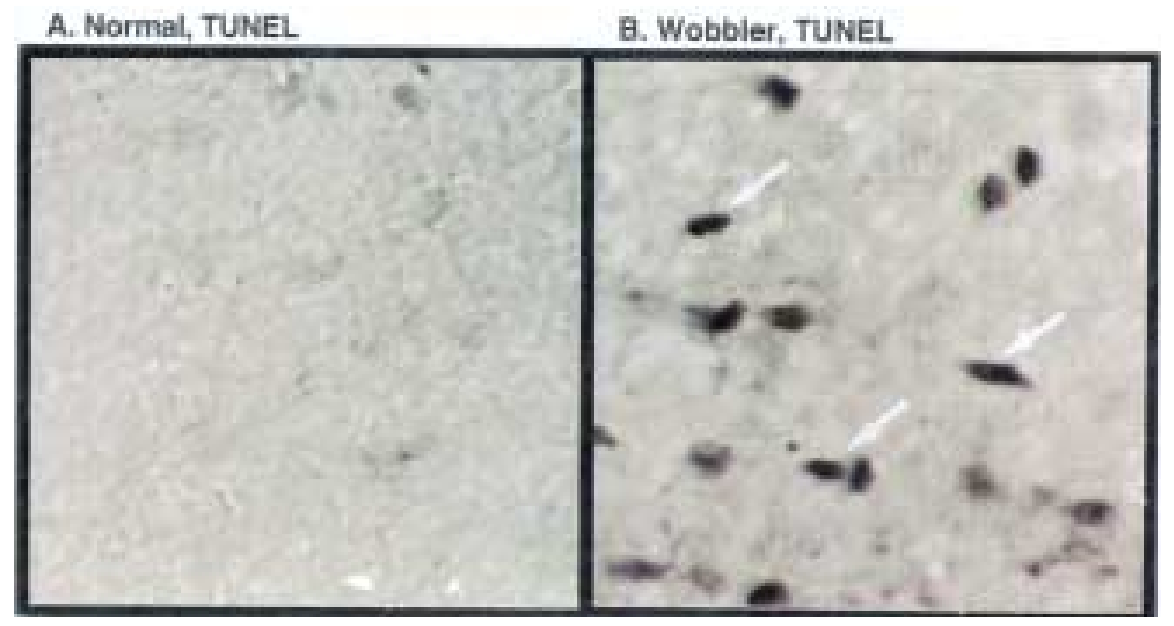

Fig. 7. Cell death in wobbler (postnatal day 21) spinal cords. TdT-mediated dUTP nick end labelingpositive nuclei (arrows), indicative of local DNA fragmentation, appear in wobbler cervical spinal cords (B) and are essentially absent in littermate spinal cords (A). 
with other known mechanisms that could result in motor neuron death, we examined PAR-1 expression prior to phenotypic expression.

To accomplish this, we turned to the powerful technique of genotyping preclinical wobbler mice, using techniques previously developed (18). The NZB strain harbored a polymorphism in the intronless glutamine synthetase pseudogene (glns1) that was tightly linked to the wobbler (wr) locus (16). This enabled preclinical diagnosis of the $w r$ genotype. Since the background strain (NFR obtained from NIH) upon which our wobbler colony was bred possessed a microsatellite of the glns 1 that migrated faster in agarose gels (162 bp), compared with the NZB (188 bp) mice, we backcrossed obligate preclinical wobblers with NZB and obtained informative matings in the third generation (Fig. 8). We then obtained both DNA and RNA from embryonic (E12-18) and postnatal (P0-P45) times and performed qRTPCR with mimic PAR-1 mRNA (36). The results of this study are shown in Figure 9 and Table 3. In control animals, PAR-1 was biphasic, with high to low levels in the embryonic spinal cord and a second peak during postnatal throughout development and continued at low levels in the adult. In stark contrast, $w r / w r$ mice display elevated PAR-1 expression as early as E12 in development (Fig. 9), which continued at this level into adulthood, with a possible further increase ( 8 fold) in the early postnatal period (Table 3 ). This elevation preceded the loss of motor neurons (22) and indicated the potential involvement of PAR-1 in important early signaling events responsible for motor neuron loss.

\section{Discussion}

As a model for understanding the underlying molecular interactions that occur during neurodegeneration, studies of the wobbler mutant mouse, where cervical motor neurons are lost during the first three weeks of life and loss of motor function results, have been quite useful. Astrocytosis is prominent in wobbler spinal cords (52; Fig. 1), suggesting an abnormal cellular interaction involving glutamine synthetase (56). Early on, we noted that wr/wr spinal cord astrocytes (37) resembled astrocytes exposed to thrombin (57). Published data indicated that astrocytes were the cells responsible for production of prothrombin mRNA (49) in embryonic rat brain (46) and we first asked whether astrocytes might be producing excess thrombin in wobbler. In fact, adult $w r / w r$ astrocytes produce greater amounts of active thrombin than their wt littermates. Since thrombin has been shown to

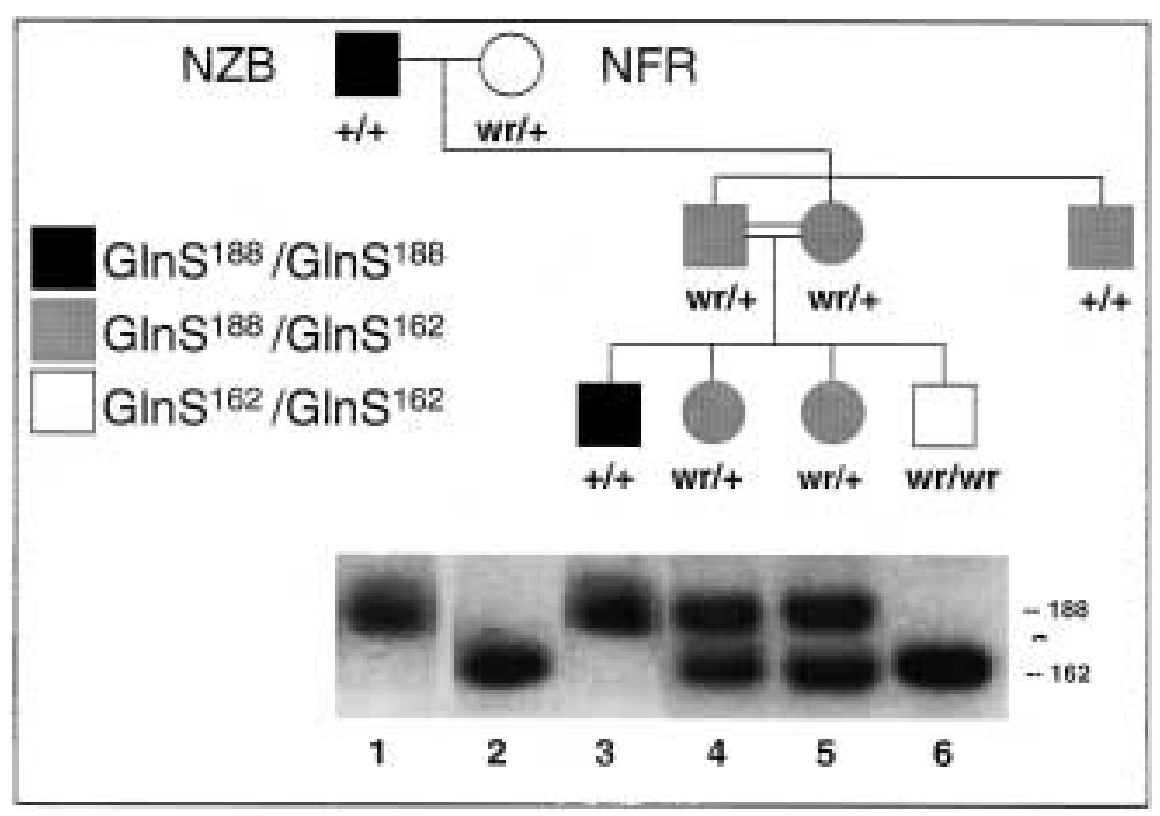

Fig. 8. Preclinical detection of $w r / w r$. Genetic diagnosis with the tightly linked $(\sim 1 \%$ recombination) Glns polymorphism, detectable by PCR amplification, per "Materials and Methods," enables identification of homozygous wr/wr mice, such as the mouse in lane 6, prior to the onset of symptoms, facilitating the investigation of PAR-1 changes in embryos or early neonates. 


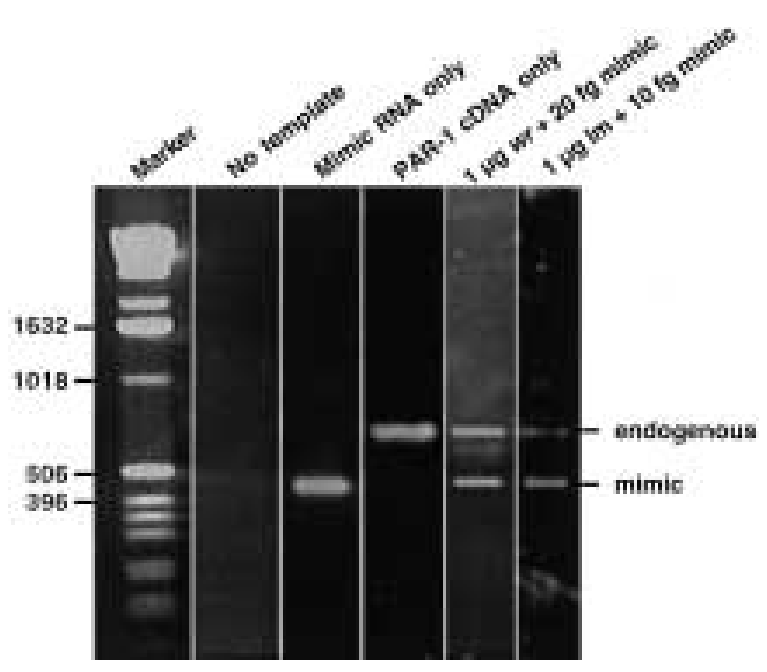

Fig. 9. PAR-1 mRNA expression in early embryonic $w r / w r$ spinal cords. qRT-PCR analysis of PAR-1 message was determined as early as E12. Titrations of endogenous and PAR-1 mimic RNA (36) gave consistent results and are summarized in Table 3.

kill motoneurons in culture by triggering the PAR-1 receptor and we previously reported increased PAR-1 message in $w r / w r$ spinal cord RNA (36), motoneurons might be vulnerable to "death signals" produced by astrocytes.

We now report the first demonstration of up-regulated PAR-1 expression in a spontaneous, naturally occurring disease in situ. While this manuscript was in preparation, PAR-1 overexpression in highly metastatic human breast carcinoma cell lines and biopsy specimens was reported (58). PAR-1 expression directly affected cancer cell behavior, since PAR-1 antisense cDNA inhibited metastasis (59). In postmitotic neurons, thrombin would not be mitogenic but is in fact, apoptogenic in these cells $(28,29,33-35)$. Indicating a role in development, PAR-1 null (-/-) mice show profound effects of the disrupted allele on embryonic survival $(38,60)$. It is of interest to consider whether antisense PAR-1 oligonucleotides treatment would affect up-regulation in wobbler motoneurons and whether this would be neuroprotective against progressive motoneuron cell death.

Although the initial studies showing that thrombin-activated PAR-1 induced apoptotic cell death were performed with neurons, these were primary rat hippocampal neurons grown under stress conditions $(28,29,35)$. These cells are much less sensitive to thrombin under normal conditions (61). In the absence of a stress stimulus, model $(32,33)$ and primary motor neurons $(33,34,62,63)$ are much more susceptible to thrombin's killing effects. In contrast to -/- mice, all transgenic mice overexpressing PAR-1 survive, but with behavioral abnormalities (Stevens, et al., unpublished). In the absence of CNS-targeting, clearly none of these effects are mediated via platelets, the cells originally used to clone PAR-1 (64). In this regard, PAR-1 overexpression in $w r / w r$ spinal cord, in Western blots, immunohistochemistry and nucleic acid studies, was greatest in cervical cord motoneurons (Figs. 2-5), where the degeneration is most prominent (Fig. 1; 22,65,66). Parallel analyses of the cerebellum or of thoracolumbar cords by these methods consistently shows that the dramatic increases in PAR-l are restricted to the clinically affected cervical regions (Figs. 3, 5), suggesting that tissue and inducer-specific regulators may be involved.

The results with normal $w t$ littermates establish that PAR-1 is expressed in the mouse

Table 3. Copies of PAR-1 mRNA per $\mu$ g total RNA in $w r / w r$ and $w t$ littermate spinal cords throughout development ${ }^{1}$

\begin{tabular}{|c|c|c|c|c|c|c|}
\hline \multirow{2}{*}{$\begin{array}{l}\text { Age } \\
\text { E12 }\end{array}$} & \multicolumn{2}{|c|}{ Littermate $(w t)$} & \multirow{2}{*}{$\begin{array}{l}(n) \\
(3)\end{array}$} & \multicolumn{2}{|c|}{$w r / w r$} & \multirow{2}{*}{$\begin{array}{l}(n) \\
(2)\end{array}$} \\
\hline & 11,700 & \pm 2600 & & 49,200 & \pm 7400 & \\
\hline B & 6,300 & \pm 1300 & $(2)$ & 37,000 & \pm 7700 & (2) \\
\hline P5 & 10,500 & & $(1)$ & 80,200 & & (1) \\
\hline P18 & 11,200 & \pm 2200 & $(2)$ & 51,600 & & (1) \\
\hline P28 & 8,800 & \pm 1000 & $(5)$ & 47,800 & \pm 8300 & $(4)$ \\
\hline
\end{tabular}

\footnotetext{
${ }^{1}$ Mice were genotyped as in "Materials and Methods." mRNA levels were determined for 26 mice and compared between $w r / w r$ homozygotes and their wild-type littermates and reported as mean \pm S.E.M.
} 
spinal cord, as it is in the rat (55), primarily in motor neurons $(50,67,68)$. Although the reasons for this are not immediately apparent, a recently completed developmental study of PAR-1 and prothrombin gene expression in mouse spinal cord (Citron et al, submitted) further shows that the spinal cord lags behind the forebrain $(67,68)$, with both transcripts detected well after birth. At the protein level, $w t$ motor neurons exhibit fine-membrane staining more prominently than small interneurons and glial cells (Figs. 3A and 3B). In contrast, in affected $w r / w r$ spinal cords, PAR-1 antigen appears to fill all remaining motor neurons, many of normal size and shape (Figs. 3C and D). The high correlation between PAR-1 protein and mRNA is demonstrated by in situ hybridization (Fig. 6), showing increased expression, compared with $w t$. Both qualitative, as well as quantitative, changes in PAR-1 gene expression also are found, since diffuse staining occurs in the dorsal horn gray matter; whereas PAR-1 expression appears greatest in large motor neurons in both $w t$ and wobbler ventral horn gray matter, consistent with the phenotype. In wobbler spinal cord sections, but not in wt, much of the in situ labeling pattern is nuclear. This intense nuclear labeling suggests that PAR-1 in this specific type of motor neuronal cell death is regulated at the transcriptional level and efforts to confirm this are underway. Compared with motor neurons, other cells have weak to moderate expression of PAR-1 mRNA.

Using qRT-PCR with mimic RNA (47), we found 5-to-6-fold greater PAR-1 message in $w r / w r$ than $w t$ (36; Figs. 4C, 5; Table 3). Strikingly, despite this marked increase of PAR-1 mRNA and marked reactive gliosis with increase in GFAP (Fig. 1), the in situ studies fail to convincingly show increased PAR-1 expression in astrocytes (Fig. 6). The astrocytic response to thrombin (reversal of stellation) in culture is mediated via PAR-1 $(57,69)$, yet, this does not correlate with a PAR-1 increase in $w r / w r$ spinal cord astrocytes in vivo. Our results do suggest, however, a pathologic interaction between wobbler astrocytes releasing thrombin and the overexpression of PAR-1 in alpha motor neurons.

Increased PAR-1 expression occurs as early as E12 (Figure 9 and Table 3), peaks shortly after birth, and then declines. Collection of spinal cords from earlier time points will strengthen these observations and further al- low counts of islet-1/2 positive motoneurons $(24,25)$, along with islet-negative interneurons and astrocytes and apoptosis indices to establish the relationship between PAR-1 expression and motoneuron loss. The delayed onset of motor neuron loss in wobbler has led to its more recent use in the study of motor neuron cell death. Although pathologic, postnatal apoptosis has been found in other mouse mutations, (70-73), apoptosis has not been established firmly in wobbler motor neurons (73). This is significant since both $b c l$-2-independent and -dependent pathways have been reported in wobbler (20). Despite protection for developmental and injury-induced neonatal cell death, cervical cord motor neurons of $b c l-2$ transgenic mice crossed with wr/wr still underwent pathological cell death (21). Thus, embryonic, experimental and pathological motor neuronal death may be separated by dependence on potentially distinct mechanisms.

As shown in Figure 7, there are suggestions that apoptosis may be involved for some motoneurons in $w r / w r$ mice. We found TUNEL-positive cells at earlier, but less at later, postnatal times. TUNEL-positive cells have been reported in wobbler spinal cord cells, although at P28, these apparently were not motor neurons (73). We are now examining earlier embryonic times to more carefully re-evaluate the mechanisms of cell loss. Our own data suggest that other types of cell death, such as oncosis $(74,75)$, may co-exist with apoptosis in the wobbler model (Zoubine et al., unpublished).

PAR-1 is not the gene defect in wobbler, which is located on proximal mouse chromosome 11 (15), where it is linked both to rabl (16) and Glns-ps1 (18). However, the fact that PAR-1 expression follows the known degeneration burden (cervical > lumbar) noted in the literature $(22,65,66)$ suggests that it plays a role in the pathogenesis of motor neuron loss. Of interest, ras genes, such as rabl, have been found in platelets (76), as well as in neurons, where they are involved both in synaptic vesicle docking $(77,78)$ and in post-Golgi trafficking $(79,80)$. PAR-1 $(c f 2 r$, for coagulation factor II receptor) is located on mouse chromosome $13(81)$, in a region syntenic with human 5q1314. This is the same locus for the survival motor neuron (smn) and neuronal apoptosis inhibitor protein (naip) genes, both critical for survival and implicated in motor neuron diseases such as SMA (82). Just what interactions 
these small G proteins and motor neuron survival genes have with PARs must await further studies. Regardless of this, since PAR-1 activation by thrombin induces apoptotic neuronal death (28-30) and involves small G-proteins $(33,35,83)$, these results have potential consequences for neurodegeneration. One therapeutic avenue to employ (84) might be the potential use of 3-hydroxy-3-methylglutaryl coenzyme A (HMG CoA) reductase inhibitors, so-called "statin" drugs, since they interfere with the isoprenylation of Rho (85). We have found that they are neuroprotective in cultured motoneurons treated with thrombin and TRAP-6 (Smirnova et al, submitted).

PAR-1 dramatically mobilizes calcium in motor neurons (54), as it does in other cells (86). This is closely associated with several modes of cell death (87), including necrosis and oncosis, as well as apoptosis $(74,75,88)$. This receptor alone appears to account totally for the response to thrombin, since fibroblasts derived from PAR-1 knockout mice do not respond to thrombin signaling by calcium influx unless these cells are transfected with an exogenous human PAR-1 gene (86). On a speculative basis, thrombin-activated PAR-1 mobilization of calcium in motor neurons might provide a death-inducing mechanism, since these cells may be especially vulnerable to increased $\left[\mathrm{Ca}^{2+}\right]_{\mathrm{i}}$, due to underexpression of several calcium-binding proteins, such as calbindin and parvalbumin (89-91). Reduced parvalbumin expression may underlie the selective vulnerability of motor neurons in ALS and other human motor neuron diseases $(91,92)$. In a recent in situ hybridization study, parvalbumin, not calbindin-D28K, calretinin or calmodulin, identified ALS-resistant motor neurons (90). This may also underscore selective vulnerability of spinal cord motoneurons in wobbler. Although reduced calcium-binding proteins have been reported in $w r / w r$ muscle $(93,94)$, they have not been studied in spinal cord. Since thrombin acts as an extracellular death signal to activate motor neuron intracellular cysteine proteases (caspases) which cleave various substrates involved in cellular repair $(33,34)$, apoptotic execution of motoneuron cell death may progress inexorably.

In summary, our current results demonstrate that in phenotypic degenerating $\mathrm{wr} / \mathrm{wr}$ spinal cord, where motor neurons are progressively lost, astrocytes produce higher levels of thrombin, compared with wild type cells. In these same cords, an antibody specific for PAR-1 shows markedly increased protein levels of this thrombin receptor on $w r / w r$ motor neurons in the ventral horn of cervical cord segments. Based on previous results showing that thrombin is synthesized at low levels within the developing spinal cord and that it induces motor neuron death through activating PAR-1, we reported that mRNA for PAR-1 was also up-regulated in phenotypic $w r / w r$ mice (36). We now have found that both increased protein and mRNA expression is greater in cervical, compared with lumbar, spinal cords. This was previously shown to bear the greatest burden of disease in this model and was restricted to motor neurons (22). These results were further supported by finding quantitatively increased levels of PAR-1 mRNA, relative to mimic controls and GAPDH message, in extracts from developing $w r$ cervical, compared with the wild type or $w r$ lumbar spinal regions as early as embryonic day 12.5 , preceding the onset of degeneration and phenotypic findings.

These results imply a pathogenetic role for PAR-1 and thrombin protease signaling in this inherited CNS degeneration. Pathologic interaction between thrombin-releasing reactive astrocytes and motor neurons overexpressing PAR-1 may be involved in the wobbler phenotype. A potential interaction between protease signaling and motoneuron viability may depend, in part, on the PAR-1 locus with the naip and smn genes on mouse chromosome 13 and in human ALS or SMA at 5q13. Although the relevance of interaction between these genes on motoneuron survival must await future studies, similar influences of the thrombin signal transduction pathway on neuronal function and survival may also be found in human neurodegenerations, as well as in ischemic stroke and after neural injury (95). If so, then neuroprotective signal transduction strategies (84) may, indeed, become a rational molecular approach to prevent and/or reverse such processes.

\section{Acknowledgments}

The authors are especially grateful for the technical support of Christina J. Rogahn and Dr. Mikhail N. Zoubine and to Dr. Virginia SmithSwintosky for critical reading of the manu- 
script. Dr. Djennet Hantaz-Ambose performed adult murine spinal cord astrocyte cultures and provided $w t$ and $w r / w r$ conditioned media. These studies were supported, in part, by the Medical Research Service of the Department of Veterans Affairs; the ALS/Spinal Cord Research Fund of the Kansas University Endowment Association; the Christopher Reeve Paralysis Foundation; the American Paraplegia Society; the Research Institute, Inc., of the University of Kansas Medical Center; the Defense and Veterans Head Injury Program, Uniformed Services University of the Health Sciences, Bethesda, MD; and the R. W. Johnson Pharmaceutical Research Institute, Spring House, PA.

\section{References}

1. $\mathrm{Su} \mathrm{JH}$, Anderson AJ, Cummings BJ, Cotman CW. (1994) Immunohistochemical evidence for apoptosis in Alzheimer's disease. Neuroreport 5: 2529-2533.

2. Cotman CW. (1998) Apoptosis decision cascades and neuronal degeneration in Alzheimer's disease. Neurobiol. Aging 19: S29-32.

3. Rosen DR, Siddique T, Patterson D, et al. (1993) Mutations in $\mathrm{Cu} / \mathrm{Zn}$ superoxide dismutase gene are associated with familial amyotrophic lateral sclerosis. Nature 362: 59-62.

4. Bowling AC, Schulz JB, Brown RH, Beal MF. (1993) Superoxide dismutase activity, oxidative damage, and mitochondrial energy metabolism in familial and sporadic amyotrophic lateral sclerosis. J. Neurochem. 61: 2322-2325.

5. Cleveland DW, Laing N, Hurse PV, Brown RH. (1995) Toxic mutants in Charcot's sclerosis. $\mathrm{Na}$ ture 378: 342-343.

6. Brown RH. (1995) Amyotrophic lateral sclerosis: recent insights from genetics and transgenic mice. Cell 80: 687-692.

7. Dal Canto MC, Gurney ME. (1995) Neuropathological changes in two lines of mice carrying a transgene for mutant human $\mathrm{Cu}, \mathrm{Zn}$ SOD, and in mice overexpressing wild type human SOD: a model of familial amyotrophic lateral sclerosis (FALS). Brain Res. 676: 25-40.

8. Rabizadeh S, Gralla EB, Borchelt DR, et al. (1995) Mutations associated with amyotrophic lateral sclerosis convert superoxide dismutase from an antiapoptotic gene to a proapoptotic gene: studies in yeast and neural cells. Proc. Natl. Acad. Sci. U.S.A. 92: 3024-3028.

9. Yim MB, Kang JH, Yim HS, Kwak HS, Chock PB, Stadtman ER. (1996) A gain-of-function of an amyotrophic lateral sclerosis-associated $\mathrm{Cu}, \mathrm{Zn}$-superoxide dismutase mutant: an en- hancement of free radical formation due to a decrease in $\mathrm{Km}$ for hydrogen peroxide. Proc. Natl. Acad. Sci. U.S.A. 93: 5709-5714.

10. Wiedau-Pazos M, Goto JJ, Rabizadeh S, et al. (1996) Altered reactivity of superoxide dismutase in familial amyotrophic lateral sclerosis. Science 271: 515-518.

11. Brown RH. (1994) A transgenic-mouse model of amyotrophic lateral sclerosis. N. Engl. J. Med. 331: 1091-1092.

12. Pioro EP, Mitsumoto H. (1996) Animal models of ALS. Clin. Neurosci. 3: 375-385.

13. Falconer DS. (1956) Wobbler (wr). Mouse News Let. 15: 23-29.

14. Duchen LW, Strich SS. (1968) An hereditary motor neuron disease with progressive denervation of muscle in the mouse: the mutant wobbler. J. Neurol. Neurosurg. Psychiatry 31: 535-542.

15. Kaupmann K, Simon Chazottes D, Guenet JL, Jockusch H. (1992) Wobbler, a mutation affecting motoneuron survival and gonadal functions in the mouse, maps to proximal chromosome 11. Genomics 13: 39-43.

16. Wedemeyer $\mathrm{N}$, Lengeling $\mathrm{A}$, Ronsiek $\mathrm{M}$, et al. (1996) YAC contigs of the Rabl and wobbler (wr) spinal muscular atrophy gene region on proximal mouse chromosome 11 and of the homologous region on human chromosome $2 \mathrm{p}$. Genomics 32: 447-454.

17. Wichmann H, Jockusch H, Guenet JL, Gallwitz D, Kaupmann K. (1992) The mouse homolog to the ras-related yeast gene YPT1 maps on chromosome 11 close to the wobbler (wr) locus. Mamm. Genome 3: 467-468.

18. des Portes V, Coulpier M, Melki J, Dreyfus PA. (1994) Early detection of mouse wobbler mutation: a model of pathological motoneurone death. Neuroreport 5: 1861-1864.

19. Junier MP, Coulpier M, Le Forestier N, et al. (1994) Transforming growth factor alpha (TGF alpha) expression in degenerating motoneurons of the murine mutant wobbler: a neuronal signal for astrogliosis? J. Neurosci. 14: 4206-4216.

20. Ait-Ikhlef A, Murawsky M, Blondet B, Hantaz Ambroise D, Martinou JC, Rieger F. (1995) The motoneuron degeneration in the wobbler mouse is independent of the overexpression of a $\mathrm{Bcl} 2$ transgene in neurons. Neurosci. Lett. 199: 163-166.

21. Coulpier M, Junier MP, Peschanski M, Dreyfus PA. (1996) Bcl 2 sensitivity differentiates two pathways for motoneuronal death in the wobbler mutant mouse. J. Neurosci. 16: 5897-5904.

22. Pollin MM, McHanwell S, Slater CR. (1990) Loss of motor neurons from the median nerve motor nucleus of the mutant mouse "wobbler." J. Neurocytol. 19: 29-38.

23. Bose $\mathrm{P}$, Fielding R, Ameis KM, Vacca-Galloway LL. (1998) A novel behavioral method to detect 
motoneuron disease in Wobbler mice aged three to seven days old. Brain Res. 813: 334-342.

24. Ericson J, Thor S, Edlund T, Jessell TM, Yamada T. (1992) Early stages of motor neuron differentiation revealed by expression of homeobox gene Islet-1. Science 256: 1555-1560.

25. Ericson J, Morton S, Kawakami A, Roelink H, Jessell TM. (1996) Two critical periods of Sonic Hedgehog signaling required for the specification of motor neuron identity. Cell 87: 661-673.

26. Mourelatos Z, Gonatas NK, Stieber A, Gurney ME, Dal Canto MC. (1996) The Golgi apparatus of spinal cord motor neurons in transgenic mice expressing mutant $\mathrm{Cu}, \mathrm{Zn}$ superoxide dismutase becomes fragmented in early, preclinical stages of the disease. Proc. Natl Acad. Sci. U.S.A. 93: 5472-5477.

27. Dal Canto MC, Gurney ME. (1997) A low expressor line of transgenic mice carrying a mutant human $\mathrm{Cu}, \mathrm{Zn}$ superoxide dismutase (SODl) gene develops pathological changes that most closely resemble those in human amyotrophic lateral sclerosis. Acta Neuropathol (Berl) 93: 537-550.

28. Vaughan PJ, Pike CJ, Cotman CW, Cunningham DD. (1995) Thrombin receptor activation protects neurons and astrocytes from cell death produced by environmental insults. J. Neurosci. 15: 5389-5401.

29. Smith-Swintosky VL, Zimmer S, Fenton JW, II, Mattson MP. (1995) Protease nexin-1 and thrombin modulate neuronal $\mathrm{Ca} 2+$ homeostasis and sensitivity to glucose deprivation-induced injury. J. Neurosci. 15: 5840-5850.

30. Festoff BW, Nelson PG, Brenneman DE. (1996) Prevention of activity-dependent neuronal death: vasoactive intestinal polypeptide stimulates astrocytes to secrete the thrombin-inhibiting, neurotrophic serpin, protease nexin I. J. Neurobiol. 30: 255-266.

31. Donovan FM, Cunningham DD. (1998) Signaling pathways involved in thrombin-induced cell protection. J. Biol. Chem. 273: 12746-12752.

32. Smirnova IV, Citron BA, Arnold PM, Festoff BW. (1996) Thrombin mimics serum withdrawal causing apoptosis in model motor neurons. Am. Soc. Cell Biol. Abs. 7: 1115.

33. Smirnova IV, Zhang SX, Citron BA, Arnold PM, Festoff BW. (1998) Thrombin is a death signal that activates intracellular death protease pathways in motor neurons. J. Neurobiol. 36: $64-80$.

34. Turgeon VL, Lloyd ED, Wang S-W, Festoff BW, Houenou LJ. (1998) Thrombin perturbs neurite outgrowth and induces apoptotic cell death in chick spinal motoneuron cultures through caspase activation. J. Neurosci. 18: 6882-6891.

35. Donovan FM, Pike CJ, Cotman CW, Cunningham DD. (1997) Thrombin induces apoptosis in cultured neurons and astrocytes via a pathway requiring tyrosine kinase and RhoA activities. J. Neurosci. 17: 5316-5326.

36. Salcedo RM, Festoff BW, Citron BA. (1998) Quantitative reverse transcriptase PCR to gauge increased protease-activated receptor 1 (PAR-1) mRNA copy numbers in the Wobbler mutant mouse. J. Mol. Neurosci. 10: 113-119.

37. Hantaz-Ambroise D, Blondet B, Murawsky M, Rieger F. (1994) Abnormal astrocyte differentiation and defective cellular interactions in wobbler mouse spinal cord. J. Neurocytol. 23: 179-192.

38. Darrow AL, Fungleung WP, Ye RD, et al. (1996) Biological consequences of thrombin receptor deficiency in mice. Thrombos. Haemostas. 76: 860-866.

39. Smith-Swintosky VL, Cheo-Isaacs CT, $D^{\prime}$ Andrea MR, Santulli RJ, Darrow AL, Andrade-Gordon P. (1997) Protease-activated receptor-2 (PAR-2) is present in the rat hippocampus and is associated with neurodegeneration. J. Neurochem. 69: 1890-1896.

40. Cheung WM, D'Andrea MR, Andrade-Gordon P, Damiano BP. (1999) Altered vascular injury responses in mice deficient in protease-activated receptor-1. Arterioscler. Thromb. Vasc. Biol. 19: 3014-3024.

41. D'Andrea MR, Derian CK, Leturcq D, et al. (1998) Characterization of protease-activated receptor-2 immunoreactivity in normal human tissues. J. Histochem. Cytochem. 46: 157-164.

42. Smirnova IV, Citron BA, Arnold PM, Zhang SX, Festoff BW. (1998) Characterization of apoptosis in a motor neuron cell line. Spine 23: 151-158.

43. Arce V, Garces A, de Bovis B, et al. (1999) Cardiotrophin-1 requires LIFRbeta to promote survival of mouse motoneurons purified by a novel technique. J. Neurosci. Res. 55: 119-126.

44. Bang NU, Mattler LE. (1978) Sensitivity and specificity of plasma serine protease chromogenic substrates. Haemostasis 7: 98-104.

45. Smirnova IV, Ma JXY, Citron BA, et al. (1996) Neural thrombin and protease nexin I kinetics after murine peripheral nerve injury. J. Neurochem. 67: 2188-2199.

46. Dihanich M, Kaser M, Reinhard E, Cunningham D, Monard D. (1991) Prothrombin mRNA is expressed by cells of the nervous system. Neuron 6: 575-581.

47. Citron BA, Smirnova IV, Zoubine MN, Festoff BW. (1997) Quantitative PCR analysis reveals novel expression of prothrombin mRNA and regulation of its levels in developing mouse muscle. Thrombos. Res. 87: 303-313.

48. Kim S, Nelson PG. (1998) Transcriptional regulation of the prothrombin gene in muscle. J. Biol. Chem. 273: 11923-11929.

49. Deschepper CF, Bigornia V, Berens ME, Lapointe MC. (1991) Production of thrombin and antithrombin III by brain and astroglial cell cultures. Brain Res. Mol. Brain Res. 11: 355-358. 
50. Soifer SJ, Peters KG, O'Keefe J, Coughlin SR. (1994) Disparate temporal expression of the prothrombin and thrombin receptor genes during mouse development. Am. J. Pathol. 144: 60-69.

51. Fenton JW, Villanueva GB, Ofosu FA, Maraganore JM. (1991) Thrombin inhibition by hirudin: how hirudin inhibits thrombin. Haemostasis 21 (Suppl 1): 27-31.

52. Laage S, Zobel G, Jockusch H. (1988) Astrocyte overgrowth in the brain stem and spinal cord of mice affected by spinal atrophy, wobbler. Dev. Neurosci. 10: 190-198.

53. Kim DW, Wang F, Ramakrishnan S, et al. (1994) Mouse fibroblasts defective in thrombin mitogenesis possess functional proteolytically activated receptor for thrombin: requirement for a second signaling pathway. J. Cell Physiol. 160: 573-584.

54. Smirnova IV, Vamos S, Wiegmann T, Citron BA, Arnold PM, Festoff BW. (1998) Calcium mobilization and protease-activated receptor cleavage after thrombin stimulation in motor neurons. J. Molec. Neurosci. 10: 31-44.

55. Niclou SP, Suidan HS, Pavlik A, Vejsada R, Monard D. (1998) Changes in the expression of protease-activated receptor 1 and protease nexin-1 mRNA during rat nervous system development and after nerve lesion. Eur. J. Neurosci. 10: 1590-1607.

56. Blondet B, Hantaz-Ambroise D, Ait-Ikhlef A, Cambier D, Murawsky M, Rieger F. (1995) Astrocytosis in wobbler mouse spinal cord involves a population of astrocytes which is glutamine synthetase-negative. Neurosci. Lett. 183: 179-182.

57. Beecher KL, Andersen TT, Fenton JW, Festoff BW. (1994) Thrombin receptor peptides induce shape change in neonatal murine astrocytes in culture. J. Neurosci. Res. 37: 108-1 15.

58. Even-Ram S, Uziely B, Cohen P, et al. (1998) Thrombin receptor overexpression in malignant and physiological invasion processes. Nat. Med. 4: 909-914.

59. Nierodzik ML, Chen K, Takeshita K, et al. (1998) Protease-activated receptor 1 (PAR-1) is required and rate-limiting for thrombinenhanced experimental pulmonary metastasis, Blood 92: 3694-3700.

60. Connolly AJ, Ishihara H, Kahn ML, Farese RV, Coughlin SR. (1996) Role of the thrombin receptor in development and evidence for a second receptor. Nature 381: 516-519.

61. Brewer GJ. (1995) Exogenous thrombin inhibits neuritogenesis in cultured neuroblastoma cells but not in rat hippocampal neurons. Brain Res. 683: 258-263.

62. Turgeon VL, Houenou LJ. (1999) Prevention of thrombin-induced motoneuron degeneration with different neurotrophic factors in highly enriched cultures. J. Neurobiol. 38: 571-580.
63. Turgeon VL, Milligan CE, Houenou LJ. (1999) Activation of the protease-activated thrombin receptor (PAR)-1 induces motoneuron degeneration in the developing avian embryo. J. Neuropathol. Exp. Neurol. 58: 499-504.

64. Vu TK, Hung DT, Wheaton VI, Coughlin SR. (1991) Molecular cloning of a functional thrombin receptor reveals a novel proteolytic mechanism of receptor activation. Cell 64: 1057-1068.

65. Andrews JM. (1975) The fine structure of the cervical spinal cord, ventral root and brachial nerves in the wobbler (wr) mouse. J. Neuropathol. Exp. Neurol. 34: 12-27.

66. Biscoe TJ, Lewkowicz SJ. (1982) Quantitative light and electron microscopic studies on the ventral roots of the wobbler mutant mouse. Q. $J$. Exp. Physiol. 67: 543-555.

67. Niclou S, Suidan HS, Brown-Luedi M, Monard D. (1994) Expression of the thrombin receptor mRNA in rat brain. Cell Molec. Biol. 40: 42 1-428.

68. Weinstein JR, Gold SJ, Cunningham DD, Gall CM. (1995) Cellular localization of thrombin receptor mRNA in rat brain: expression by mesencephalic dopaminergic neurons and codistribution with prothrombin mRNA. J. Neurosci. 15: 2906-2919.

69. Grand RJA, Turnell AS, Grabham PW. (1996) Cellular consequences of thrombin-receptor activation. Biochem. J. 313: 353-368.

70. Norman DJ, Feng L, Cheng SS, Gubbay J, Chan E, Heintz N. (1995) The lurcher gene induces apoptotic death in cerebellar Purkinje cells. Development 121: 1183-1193.

71. van der Hoeven F, Schimmang T, Volkmann A, Mattei MG, Kyewski B, Ruther U. (1994) Programmed cell death is affected in the novel mouse mutant Fused toes (Ft). Development 120: 2601-2607.

72. Zakeri ZF, Ahuja HS. (1994) Apoptotic cell death in the limb and its relationship to pattern formation. Biochem. Cell Biol. 72: 603-613.

73. Popper P, Farber DB, Micevych PE, Minoofar K, Bronstein JM. (1997) TRPM-2 expression and TUNEL staining in neurodegenerative diseases: studies in wobbler and rd mice. Exp. Neurol. 143: 246-254.

74. Majno G, Joris I. (1995) Apoptosis, oncosis, and necrosis. An overview of cell death. Am. J. Pathol. 146: 3-15.

75. Trump BF, Berezesky IK, Chang SH, Phelps PC. (1997) The pathways of cell death: oncosis, apoptosis, and necrosis. Toxicol. Pathol. 25: 82-88.

76. Karniguian A, Zahraoui A, Tavitian A. (1993) Identification of small GTP-binding rab proteins in human platelets: thrombin-induced phosphorylation of rab3B, rab6, and rab8 proteins. Proc. Natl. Acad. Sci. U.S.A. 90: 7647-7651.

77. Fang Y, Durgerian S, Basarsky TA, Haydon PG. (1994) GTP-binding proteins: necessary components of the presynaptic terminal for synaptic 
transmission and its modulation. Adv. Sec. Mess. Phospho. Res. 29: 121-132.

78. Cussac D, Leblanc P, L'Heritier A, et al. (1996) Rho proteins are localized with different membrane compartments involved in vesicular trafficking in anterior pituitary cells. Mol. Cell Endocrinol. 119: 195-206.

79. Cappai R, Osborn AH, Gleeson PA, Handman E. (1993) Cloning and characterization of a Golgiassociated GTP-binding protein homologue from Leishmania major. Mol. Biochem. Parasitol. 62: $73-82$.

80. Deretic D. (1997) Rab proteins and post-Golgi trafficking of rhodopsin in photoreceptor cells. Electrophoresis 18: 2537-2541.

81. Poirier C, O'Brien EP, Bueno Brunialti AL, Chambard J, Swank RT, Guenet J. (1996) The gene encoding the thrombin receptor (Cf2r) maps to mouse chromosome 13. Mamm. Genome 7: 322.

82. Morrison KE. (1996) Advances in SMA research: review of gene deletions. Neuromuscul. Disord. 6: 397-408.

83. Verrall S, Ishii $M$, Chen $M$, Wang L, Tram T, Coughlin SR. (1997) The thrombin receptor second cytoplasmic loop confers coupling to Gqlike G proteins in chimeric receptors. Additional evidence for a common transmembrane signaling and $G$ protein coupling mechanism in $G$ protein-coupled receptors. J. Biol. Chem. 272: 6898-6902.

84. Festoff BW. (1997) Clinical potential of agents that affect thrombin signaling in degenerative and traumatic neurologic disorders. In: Mattson, MP (ed.) Neuroprotective Signal Transduction. Humana Press, Totowa, NJ, pp. 221-241.

85. Essig M, Nguyen G, Prie D, Escoubet B, Sraer JD, Friedlander G. (1998) 3-Hydroxy-3-methylglutaryl coenzyme A reductase inhibitors increase fibrinolytic activity in rat aortic endothelial cells. Role of geranylgeranylation and Rho proteins. Circ. Res. 83: 683-690.
86. Hammes SR, Coughlin SR. (1999) Proteaseactivated receptor-1 can mediate responses to SFLLRN in thrombin-desensitized cells: evidence for a novel mechanism for preventing or terminating signaling by PARl's tethered ligand. Biochemistry 38: 2486-2493.

87. Orrenius S, Nicotera P. (1994) The calcium ion and cell death. J. Neural Transm. Suppl. 43: 1-11.

88. Trump BF, Berezesky IK. (1996) The role of altered $[\mathrm{Ca} 2+] \mathrm{i}$ regulation in apoptosis, oncosis, and necrosis. Biochim. Biophys. Acta 1313: 173-178.

89. Ince P, Stout N, Shaw P, et al. (1993) Parvalbumin and calbindin D-28k in the human motor system and in motor neuron disease. Neuropathol. Appl. Neurobiol. 19: 291-299.

90. Elliott JL, Snider WD. (1995) Parvalbumin is a marker of ALS-resistant motor neurons. Neuroreport 6: 449-452.

91. Alexianu ME, Ho BK, Mohamed AH, La Bella V, Smith RG, Appel SH. (1994) The role of calcium-binding proteins in selective motoneuron vulnerability in amyotrophic lateral sclerosis. Ann. Neurol. 36: 846-858.

92. Appel SH, Smith RG, Alexianu M, et al. (1994) Neurodegenerative disease: autoimmunity involving calcium channels. Ann. NY Acad. Sci. 747: 183-194.

93. Sedehizade F, Klocke R, Jockusch H. (1997) Expression of nerve-regulated genes in muscles of mouse mutants affected by spinal muscular atrophies and muscular dystrophies. Muscle Nerve 20: 186-194.

94. Stuhlfauth I, Reininghaus J, Jockusch H, Heizmann CW. (1984) Calcium-binding protein, parvalbumin, is reduced in mutant mammalian muscle with abnormal contractile properties. Proc. Natl. Acad. Sci. U.S.A. 81: 4814-4818.

95. Cunningham DD, Pulliam L, Vaughan PJ. (1993) Protease nexin-1 and thrombin: injuryrelated processes in the brain. Thrombos. Haemostas. 70: 168-171. 